\title{
Artificial Ponds as Hotspots of Nitrogen Removal in Agricultural Watershed
}

\section{Min Cai}

Guangzhou University

\section{Shuai Li}

Guangzhou University

Fei Ye

Guangzhou University

\section{Yiguo Hong}

Guangzhou University

\section{Mingquan Lü}

Chongqing Institute of Green and Intelligent Technology

Huub J M Op den Camp

University of Nijmegen

Yu Wang ( $\nabla$ wangyu@gzhu.edu.cn )

Guangzhou University https://orcid.org/0000-0001-6390-8444

\section{Research Article}

Keywords: Artificial pond, Agricultural watershed, Nutrient, Nitrogen removal, Nitrous oxide

Posted Date: January 18th, 2022

DOI: https://doi.org/10.21203/rs.3.rs-1180737/v1

License: (c) (i) This work is licensed under a Creative Commons Attribution 4.0 International License.

Read Full License

Version of Record: A version of this preprint was published at Biogeochemistry on April 21st, 2022. See the published version at https://doi.org/10.1007/s10533-022-00928-6. 


\title{
Artificial Ponds as Hotspots of Nitrogen Removal in
}

\section{Agricultural Watershed}

\author{
Min Cai ${ }^{1}$, Shuai Li ${ }^{1}$, Fei Ye ${ }^{1}$, Yiguo Hong ${ }^{1}$, Mingquan Lü̈${ }^{2}$, Huub J. M. Op den \\ Camp $^{3}$ Yu Wang $^{1 *}$ \\ ${ }^{1}$ Institute of Environmental Research at Greater Bay Area, Key Laboratory for Water Quality and \\ Conservation of the Pearl River Delta, Ministry of Education, Guangzhou University, \\ Guangzhou 510006, China \\ ${ }^{2}$ Chongqing Institute of Green and Intelligent Technology, Chinese Academy of Sciences, \\ Chongqing 401122, China \\ ${ }^{3}$ Department of Microbiology, RIBES, Radboud University Nijmegen, Nijmegen, the \\ Netherlands
}

\begin{abstract}
Small waters, like ponds, are the most abundant freshwater environments, and are increasingly recognized for their function in ecosystem service delivery. In agricultural watershed, artificial ponds play an essential role in reducing nitrogen pollution. However, until now artificial ponds remain the least investigated part of water environments. The importance of microbial activities has seldom been discussed, which makes the microbial pathways and processes rates in nitrogen removal poorly understood. To illustrate the role of artificial ponds in microbial nitrogen removal in agricultural watersheds, 21 pond sediments and 11 soils are collected in an agricultural watershed of China. Results show that surface sediments in ponds carry significantly higher dissolved inorganic nitrogen $(9.1-21.9 \mathrm{mg} / \mathrm{kg})$ and total organic matter $(64.8-113.0 \mathrm{~g} / \mathrm{kg})$ compared to the surrounding agricultural soils. High rates of microbial nitrogen removal in ponds (12.4-25.5 $\mathrm{nmol} \mathrm{N} \mathrm{g}^{-1} \mathrm{~h}^{-1}$ ) are observed, which are 2-9 times higher than those in dryland soils. In pond sediments, denitrification dominates ( $>90 \% \mathrm{~N}-\mathrm{loss})$ the microbial nitrogen removal process with only a minor contribution of anaerobic ammonium oxidation. A high
\end{abstract}


potential of $\mathrm{N}_{2} \mathrm{O}$ production (up to $9.4 \mathrm{nmol} \mathrm{N} \mathrm{g}^{-1} \mathrm{~h}^{-1}$ ) occurs in ponds along with the rapid nitrogen removal. For denitrifier genes, nir gene are always more abundant than nos $Z$ gene. Additionally, the nirS gene is more abundant under flooded conditions, while nirK gene prefers higher dissolved oxygen and $\mathrm{NO}_{3}{ }^{-}$in drylands. These findings present essential information on the mechanisms of microbial nitrogen removal in ponds, and highlight the ecosystem function of ponds in agricultural watersheds.

\section{Keywords: Artificial pond, Agricultural watershed, Nutrient, Nitrogen removal, Nitrous} oxide

\section{Introduction}

Ponds are primarily defined as artificial or natural water bodies between $1 \mathrm{~m}^{2}$ and 2 ha in area, with a maximum depth of no more than $8 \mathrm{~m}$ (Oertli et al. 2005). The number of ponds is enormous globally, with an estimated number of 277 million ponds less than 1 ha in size (Downing et al. 2006). These small water bodies account for more than 90\% of the global 304 million standing waterbodies, or $30 \%$ of global standing water by surface area (Downing et al. 2006). Ponds provide a number of vital ecosystem services including hydrological regulation, conservation of biodiversity and pollution mitigation (Brazier et al. 2021; Chen et al. 2019; Mushet et al. 2020). In nutrient cycling, the burial rates for organic carbon in ponds were 20-30 times higher than that reported for other habitats on a global scale (Downing et al. 2008). Moreover, small ponds $(<0.1$ ha) make up $8.6 \%$ of the global lakes and ponds area, but contribute $15.1 \%$ of $\mathrm{CO}_{2}$ and $40.6 \%$ of $\mathrm{CH}_{4}$ emissions (Holgerson \& Raymond 2016).

Many regions are known for large numbers of small waterbodies, including the vernal pool systems in North America, Mediterranean temporary ponds in southern Europe and North Africa, ponds of arid and desert areas in South Africa and Australia (Boix et al. 2016; Dahl 2014; Hobbie 1980; Wissinger et al. 2016). The agricultural activities in Asian countries particularly benefit from pond construction (Chen et al. 2017), especially for China with approximately $42 \%$ of the

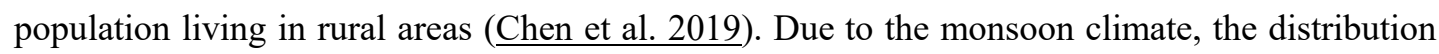
of water resources in China is extremely imbalanced spatially and temporally (Wang \& Zhang 2011), and the construction of ponds is a common mean to reserve water resources for 
agricultural irrigation and rural life (Chen et al. 2017). The history of ponds construction dates back to 3,000 years ago (Yin et al. 1993), and the number of ponds ( $<1$ ha) has reached 4 million in China to date (Lü et al. 2021).

The construction of ponds in agricultural watershed altered the landscape as well as the ecological processes. For example, artificial ponds significantly mitigated the nutrients output by intercepting and degrading the diffuse pollutants from agricultural fields and rural life sources (Capps et al. 2014). It had been reported that the traditional multi-pond systems retained about $98 \%$ of total nitrogen and phosphorus output carried by rainfall runoff in an agricultural watershed in China (Yan et al. 1998). In the United States of America, $64 \%$ of $\mathrm{NO}_{3}{ }^{-}$and $36 \%$ of total nitrogen output was abated through farm ponds in an agricultural watershed (Brunet et al. 2021). On a global scale, approximate $25 \%$ nitrogen removal of watersheds occurred in ponds and such small waterbodies (

To dates, the removal of nitrogen by artificial ponds was mostly attributed to their interception of pollutants, plant uptake and N burial in sediment (Lü et al. 2019; Verhoeven et al. 2006; Xue et al. 2020; Youn Chi \& Pandit 2012). However, microbial nitrogen transformation was seldom discussed in pond ecosystems, although it is essential for nitrogen removal. In nitrogen cycling, denitrification is generally considered as the dominant process in the freshwater

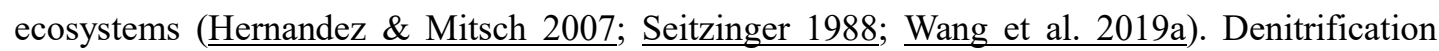
processes reduce $\mathrm{NO}_{3}^{-}$to $\mathrm{NO}_{2}^{-}, \mathrm{NO}, \mathrm{N}_{2} \mathrm{O}$, and eventually to $\mathrm{N}_{2}$, in a stepwise manner, under anaerobic conditions (Seitzinger et al. 2006). $\mathrm{N}_{2} \mathrm{O}$ and $\mathrm{N}_{2}$ are usually the two main end products in microbial nitrogen removal. Nitrite reduction catalyzed by nitrite reductase (NIR, encoded by the nirS or nirK genes) followed by NO reduction by nitric oxide reductase (NOR, encoded by nor genes) is the main source of $\mathrm{N}_{2} \mathrm{O}$ production (Kuypers et al. 2018), and $\mathrm{N}_{2} \mathrm{O}$ can be reduced to $\mathrm{N}_{2}$ via $\mathrm{N}_{2} \mathrm{O}$ reductase (encoded by the nos $\mathrm{Z}$ gene) (Hallin et al. 2018). The release of $\mathrm{N}_{2} \mathrm{O}$ which is an intermediate of denitrification is regulated by functional genes of both nitrite reductase and $\mathrm{N}_{2} \mathrm{O}$ reductase. Anammox (anaerobic ammonium oxidation) is an alternative nitrogen removal pathway to denitrification, in which $\mathrm{NH}_{4}{ }^{+}$is oxidized by $\mathrm{NO}_{2}{ }^{-}$by autotrophic anammox bacteria yielding $\mathrm{N}_{2}$ as end product (Jetten et al. 2003; Wang et al. 2012). Unlike denitrification, the anammox process is not restricted by the organic matter content and is more straightforward without emission of $\mathrm{N}_{2} \mathrm{O}$ (Cai et al. 2020; $\underline{\text { Kartal et al. 2011; }}$ Strous et al. 2006). 
Identification of the reaction rates, relative contribution, and microbial communities of the two pathways is crucial to understand the end products, environmental drivers, and processes dynamics in the nitrogen removal of artificial ponds.

In this study, a typical mountainous agricultural watershed in southwest China was selected. The land of the agricultural watershed was mainly composed of drylands, paddy fields and artificial ponds. We collected 21 sediment samples from the artificial ponds of different uses and 11 soil samples from dryland and paddy fields. By investigating the nutrient contents, microbial activities, and microbial community composition, we aim to show the roles of artificial pond (i) as nutrient reserve, (ii) in nitrogen removal of the agricultural watershed, and (iii) the major contributor in microbial nitrogen removal.

\section{Materials and methods}

\subsection{Study area and sample collection}

The study area, a mountainous agricultural watershed characterized by abundant and scattered artificial ponds, is located in Liuyin Town, Chongqing, southwest China (29 $56^{\prime} 56^{\prime \prime}-29^{\circ} 57^{\prime} 43^{\prime \prime}$ $\mathrm{N}, 106^{\circ} 37^{\prime} 12^{\prime \prime}-106^{\circ} 38^{\prime} 13^{\prime \prime}$ E) (Fig 1). The study area was approximately $13.60 \mathrm{~km}^{2}$, and the altitude was from 280 to $496 \mathrm{~m}$. It was roughly estimated that 300 artificial ponds $(<1$ ha, $\sim 0.8$ $\mathrm{km}^{2}$ in total) existed in this area for irrigation and aquaculture. In this study, sediment samples were collected from seven ponds, including four irrigation ponds (P1, P2, P5 and P6) and three aquaculture ponds (P3, P4 and P7) (Table S1). At each pond three parallel sediment columns (30 $\mathrm{cm}$ depth) and the overlying water were collected. The sediment columns were segmented into three sections $(0-10 \mathrm{~cm}, 10-20 \mathrm{~cm}$, and 20-30 cm). Three parallel surface soil samples $(0-10 \mathrm{~cm})$ in dryland or paddy fields around the ponds were collected. The crop types in dryland include corn, cowpea fields and orchard gardens.

Fig. 1 Location and distribution of sampling sites in study area

Field samples were stored in sterile plastic bags and transported to the laboratory in a 
cooler box $\left(4^{\circ} \mathrm{C}\right)$ for subsequent analysis. One subsample was immediately incubated to determine microbial nitrogen removal activity, a second subsample was used for physicochemical analyses, and a small portion was stored at $-80^{\circ} \mathrm{C}$ for molecular analysis. All samples were analyzed separately, and the values were averaged to represent site conditions.

\subsection{Physicochemical analysis}

Sediment/soil ammonium $\left(\mathrm{NH}_{4}{ }^{+}\right)$, nitrite $\left(\mathrm{NO}_{2}{ }^{-}\right)$, and nitrate $\left(\mathrm{NO}_{3}{ }^{-}\right)$were extracted from $5 \mathrm{~g}$ of fresh sediment/soil with $25 \mathrm{ml}$ of $2 \mathrm{M} \mathrm{KCl}$ (1:5 wt./vol). The supernatant was filtered through a $0.22 \mu \mathrm{m}$ membrane filter and the compounds were determined via a spectrophotometric detection assay ( $\underline{\mathrm{Wu} \text { et al. 2016) }}$. Moisture content was measured by oven-drying at $105^{\circ} \mathrm{C}$ until a constant weight was achieved. The $\mathrm{pH}$ was determined in 1:2.5 sediment/water (wt./vol) suspensions after shaking and centrifugation, with a Mettler Toledo pH analyzer (S220, Switzerland). Total organic matter (TOM) was measured as loss on ignition at $550^{\circ} \mathrm{C}$ (LOI 550) using a Muffle furnace. The TN and TP were determined with the potassium persulfate oxidation-ultraviolet spectrometry method (소 1998), using a UV spectrophotometer (UVmini-1240, Japan).

\subsection{Measurements of potential denitrification and anammox rates}

The denitrification and anammox rates of sediment/soil samples were measured using the slurry incubation and isotope pairing technique (Risgaard-Petersen et al. 2004). Fresh sediments/soils were mixed with water in the ratio of 1:7 (sediment: water) and flushed with ultrahigh purity $\mathrm{He}$ for $30 \mathrm{~min}$ to make anaerobic sediment slurries. These slurries were darkly pre-incubated at insitu temperature for 36-48 $\mathrm{h}$ to remove background $\mathrm{NO}_{\mathrm{x}}{ }^{-}\left(\mathrm{NO}_{3}{ }^{-}\right.$and $\left.\mathrm{NO}_{2}{ }^{-}\right)$and DO. After preincubation, the slurries were transferred into $12.5 \mathrm{~mL}$ tubes (Exetainers, Labco, UK) via injectors, these tubes were divided into two groups. The first group were used to analyze Fn (fraction of ${ }^{15} \mathrm{NO}_{3}^{-}$in $\mathrm{NO}_{\mathrm{x}}^{-}$pool), and the second group of tubes were injected with ${ }^{15} \mathrm{NO}_{3}^{-}(99.6$ atom\%) solution to $100 \mu \mathrm{M}$ final concentration. The tubes were incubated in the incubator at insitu temperature and were stopped by adding $200 \mu \mathrm{L}$ of $50 \% \mathrm{ZnCl}_{2}$ at 0 and $2 \mathrm{~h}$ from the beginning of incubation. ${ }^{29} \mathrm{~N}_{2}$ and ${ }^{30} \mathrm{~N}_{2}$ produced in the tubes were determined with a membrane inlet mass spectrometry (MIMS, HPR40, Hiden, UK), and the rates of denitrification and 
anammox were calculated (Thamdrup \& Dalsgaard 2002). The calculation equations are as follows:

$$
\mathrm{R}_{\mathrm{D}}=\mathrm{D}_{29}+2 \times \mathrm{P}_{30}
$$

$$
\mathrm{D}_{29}=\mathrm{P}_{30} \times 2 \times\left(1-\mathrm{F}_{\mathrm{n}}\right) \times \mathrm{F}_{\mathrm{n}}^{-1}
$$

where $\mathrm{R}_{\mathrm{D}}\left(\mathrm{nmol} \mathrm{N} \mathrm{g} \mathrm{h}^{-1}\right.$ ) represents the total rate of ${ }^{15} \mathrm{NO}_{3}{ }^{-}$- based denitrification, $\mathrm{D}_{29}$ is the ${ }^{29} \mathrm{~N}_{2}$ production rate from denitrification, $\mathrm{P}_{30}\left(\mathrm{nmol} \mathrm{N} \mathrm{g}{ }^{-1} \mathrm{~h}^{-1}\right)$ is the total ${ }^{30} \mathrm{~N}_{2}$ production rate; $\mathrm{F}_{\mathrm{n}}$ represents the fraction of ${ }^{15} \mathrm{~N}$ in total $\mathrm{NO}_{3}{ }^{-}$. The potential rates of anammox were estimated by the following equation (Wu et al. 2021; Xiao et al. 2018):

$\mathrm{R}_{\mathrm{A}}\left(\mathrm{A}_{29}\right)=\mathrm{P}_{29}-\mathrm{D}_{29}$ where $\mathrm{R}_{\mathrm{A}}\left(\mathrm{A}_{29}\right)$ and $\mathrm{P}_{29}\left(\mathrm{nmol} \mathrm{N} \mathrm{g}{ }^{-1} \mathrm{~h}^{-1}\right)$ represent the potential rate of ${ }^{15} \mathrm{NO}_{3}^{-}$- based anammox (or ${ }^{29} \mathrm{~N}_{2}$ production rate from anammox) and total ${ }^{29} \mathrm{~N}_{2}$ production rate, respectively.

\subsection{Determination of potential $\mathrm{N}_{2} \mathrm{O}$ production rate}

$\mathrm{N}_{2} \mathrm{O}$ production rates were measured with headspace equilibrium gas chromatography using the samples prepared as describes in 2.3 of Methods and Materials section (Hou et al. 2015). Specifically, the supernatant in the tubes which were incubated for $0 \mathrm{~h}$ and $2 \mathrm{~h}$ was replaced by 5 $\mathrm{mL}$ of ultrahigh purity $\mathrm{He}$ to create $5 \mathrm{~mL}$ of headspace gas. After that, the tubes were shaken violently for $1 \mathrm{~h}$ to make gas-liquid equilibrium. The concentration of $\mathrm{N}_{2} \mathrm{O}$ in the headspace gas was measured with a gas chromatograph (GC-2014C, Shimadzu, Japan) which was equipped with electron capture detector (ECD).

$\mathrm{N}_{2} \mathrm{O}$ concentrations in the headspace after equilibrium were calculated according to equation:

$$
\mathrm{C}_{\mathrm{G}}=\mathrm{P} \mathrm{C}_{\mathrm{g}} / 1013.25 \mathrm{R} \mathrm{T}
$$

where $\mathrm{C}_{\mathrm{G}}\left(\mathrm{nmol} \mathrm{L}{ }^{-1}\right)$ is the concentration of $\mathrm{N}_{2} \mathrm{O}$ in the headspace after equilibrium, $\mathrm{C}_{\mathrm{g}}$ (ppb: $\left.\mathrm{nmol} \mathrm{mol}{ }^{-1}\right)$ is the volumetric concentration of $\mathrm{N}_{2} \mathrm{O}$ in the headspace, $\mathrm{R}\left(0.082057 \mathrm{~L} \mathrm{~atm} \mathrm{~mol}^{-1}\right.$ $\mathrm{K}^{-1}$ ) is the ideal gas constant, $\mathrm{T}(\mathrm{K})$ is the temperature of the water samples after equilibrium, and $\mathrm{P}(\mathrm{hPa})$ is the pressure of laboratory.

The dissolved $\mathrm{N}_{2} \mathrm{O}$ concentrations were determined according to equation: 


$$
\mathrm{C}_{\mathrm{L}}=\mathrm{C}_{\mathrm{G}} \times\left(\mathrm{K}_{0} \mathrm{RT}+\alpha\right)
$$

where $\mathrm{C}_{\mathrm{L}}\left(\mathrm{nmol} \mathrm{L} \mathrm{L}^{-1}\right)$ is the concentration of dissolved $\mathrm{N}_{2} \mathrm{O}$ in the incubated water, $\mathrm{R}(0.082057 \mathrm{~L}$ atm $\mathrm{mol}^{-1} \mathrm{~K}^{-1}$ ) is the ideal gas constant, $\alpha$ is the ratio of gas to liquid after replacement, and $\mathrm{K}_{0}$ $\left(\mathrm{mol} \mathrm{L}^{-1} \mathrm{~atm}^{-1}\right)$ is the equilibrium constant which is calculated from Weiss formula (Weiss \&

Price 1980), as follow:

$\operatorname{lnK}_{0}=-62.7062+97.3066 \times 100 / \mathrm{T}+24.1406 \times \ln (100 / \mathrm{T})+\mathrm{S} \times[-0.05842+0.033193 \times 100 / \mathrm{T}-0.0051313 \times(100 / \mathrm{T}$

The accumulation of $\mathrm{N}_{2} \mathrm{O}$ per unit of incubation time is the rate of $\mathrm{N}_{2} \mathrm{O}$ production which was calculated according to equation:

$$
\mathrm{D}_{\mathrm{N}_{2} \mathrm{O}}=\left(\mathrm{C}_{\mathrm{L} 2}-\mathrm{C}_{\mathrm{L} 0}\right) /\left(\mathrm{T}_{2}-\mathrm{T}_{0}\right)
$$

where $\mathrm{D}_{\mathrm{N}_{2} \mathrm{O}}\left(\mathrm{nmol} \mathrm{N} \mathrm{g}^{-1} \mathrm{~h}^{-1}\right)$ is the rate of $\mathrm{N}_{2} \mathrm{O}$ production, $\mathrm{T}_{0}$ and $\mathrm{T}_{2}$ represent 0 and 2 incubation time respectively, $\mathrm{C}_{\mathrm{L} 0}$ and $\mathrm{C}_{\mathrm{L} 2}$ represent the concentration of $\mathrm{N}_{2} \mathrm{O}$ at $\mathrm{T}_{0}$ and $\mathrm{T}_{2}$ respectively.

\subsection{DNA extraction, sequencing, and data processing}

Total genomic DNA was extracted from sediment/soil samples (approximately $0.5 \mathrm{~g}$ ) using the FastDNA SPIN Kit for Soil (MP Biomedicals, USA) following the manufacturer's instruction. The concentration of extracted DNA was measured with a NanoDrop Lite (Thermo Fisher Scientific, Wilmington, DE, USA), and the DNA quality examined by $1 \%$ (wt./vol) agarose gel electrophoresis.

The nirS gene (performing $\mathrm{NO}_{2}^{-}$reduction) was used to study the denitrification community, and was amplified by PCR using primers cd3aF and R3cd (Yergeau et al. 2007). PCR amplification of Anammox - specific 16S rRNA genes was based on primers A438f and A684r ( $\underline{\text { Han \& Gu 2013). }}$. More details about the conditions of PCR amplification are presented in Table S2. Prior to high-throughput sequencing, the PCR products were purified using the MiniBEST Agarose Gel DNA Extraction Kit (TaKaRa Bio, Japan).. Subsequently, purified amplicons were pooled in equimolar and paired-end (PE) sequenced $(2 \times 300)$ on an Illumina MiSeq PE300 
platform. The raw sequences were merged and quality filtered in Quantitative Insights in Microbial Ecology (QIIME) (Caporaso et al. 2010) and Mothur (Schloss Patrick et al. 2009). OTUs with identity thresholds ( $93 \%$ for $n i r S$ and $97 \%$ for anammox $16 \mathrm{~S}$ rRNA) were defined using Usearch (v. 7.0 http://drive5.com/uparse/). Rare OTUs with less than $0.01 \%$ of the total sequences were removed. To avoid biases arising from sequencing depth and to make samples comparable, sequences were rarified to a uniform sequencing depth based on the sample with the lowest sequences. The diversity indices (Shannon, Simpson, Ace and Chao1) and rarefaction curves were calculated also in Mothur referring to previous studies (Liu et al. 2020; Ye et al. 2021). The raw sequences of nirS and Anammox-specific 16S rRNA genes used in this study were deposited in the Sequence Read Archive (SRA, https://submit.ncbi.nlm.nih.gov/subs/sra/) of NCBI under the accession numbers PRJNA780407 and PRJNA780073.

\subsection{Quantitative PCR analysis}

The abundance of bacterial 16S rRNA genes, -nir gene (nirS and nirK), nosZ gene (nosZ I and nosZ II) and anammox - specific 16S rRNA genes in sediments/soil samples were quantified by a LightCycler ${ }^{\circledR}$ R480 II Real-Time PCR (Roche, Switzerland). Each sample was analyzed in triplicate. The standard curves used for calculation were achieved with plasmid DNA with known concentrations and copy numbers. qPCR results with high amplification efficiency $(90 \%$ $110 \%)$ and correlation coefficient values of the standard curve $\left(r^{2}>0.97\right)$ were integrated into the analysis. The specificity of PCR amplifications was defined by melting curve analysis and gel electrophoresis. The primers, reaction systems, and programs are shown in Table S2.

\subsection{Statistical analysis}

Multifactor ANOVAs were used to determine the significance between samples. For factors that were statistically significant $(P<0.05)$, a Tukey's post hoc analysis was conducted to determine significant differences using the 'multcomp' package in v. R 4.1.0. The plots were conducted with Prism 8 software (version 8.0.2). Principal co-ordinates analysis (PCoA) ordination and non-metric multidimensional scaling (NMDS) was used to reveal differences in denitrification and anammox bacteria community structures based on Bray - Curtis dissimilarities. Significant 
differences among the different samples were tested by an analysis of similarities test (ANOSIM). To identify the environmental factors likely to affect the composition of denitrification and anammox bacteria communities, Canonical Correlation Analysis (CCA) was used in Canoco 5 software. Partial least squares pathway modelling (PLS-PM) was conducted in R with the 'plspm' package (Sanchez \& Trinchera 2012) to infer the effects of basic parameters (pH and moisture), nutrients (TN, TP, and TOM) and DIN $\left(\mathrm{NH}_{4}^{+}, \mathrm{NO}_{3}^{-}\right.$, and $\mathrm{NO}_{2}^{-}$) on nitrogen removal rates and associated microorganisms. 1000 bootstraps were performed on model pathways to evaluate pathway coefficients and coefficients of determination $\left(\mathrm{R}^{2}\right)$.

\section{Results}

\subsection{Physicochemical properties}

In total, 32 samples including 21 pond sediments $(7$ each for $0-10 \mathrm{~cm}, 10-20 \mathrm{~cm}$, and $20-30 \mathrm{~cm}$ depths), 7 dryland soils and 4 paddy soils were collected (Fig 2). Pond sediments were determined with the highest values of $\mathrm{NH}_{4}{ }^{+}$concentrations $(14.2 \pm 2.4 \mathrm{mg} / \mathrm{kg})$, followed by paddy soils $(7.8 \pm 3.2 \mathrm{mg} / \mathrm{kg}$ ) and dryland soils $(1.5 \pm 0.7 \mathrm{mg} / \mathrm{kg}$ ) (ANOVA, $P<0.001)$ (Fig. 2d). On the contrary, the concentrations of $\mathrm{NO}_{3}{ }^{-}$in dryland soils was significantly higher than the other two types of samples $(0.2 \pm 0.1$ and $1.1 \pm 0.7 \mathrm{mg} / \mathrm{kg}$ for sediments and paddy soils respectively, Tukey's post hoc, $P<0.001$ for both) (Fig. 2e). The highest Dissolved Inorganic Nitrogen (DIN) concentrations were observed in ponds $(14.8 \pm 2.5 \mathrm{mg} / \mathrm{kg})$, followed by the soils $(6.0 \pm 1.9$ and $9.3 \pm 2.7 \mathrm{mg} / \mathrm{kg}$ for dryland and paddy soils, Tukey’s post hoc, $P<0.001$ and $P=$ 0.009, respectively) (Fig. 2f). TOM presented high concentrations in pond sediments $(92.2 \pm$ $19.9 \mathrm{~g} / \mathrm{kg})$. The TOM in dryland soils $(56.5 \pm 16.1 \mathrm{~g} / \mathrm{kg})$ were lower than those in sediments (Tukey's post hoc, $P<0.001)$ (Fig. 2i). The pond sediments $(54.2 \pm 8.8 \%)$ had higher moisture contents than the dryland and paddy soils $(17.3 \pm 2.4 \%$ and $39.4 \pm 4.3 \%$, Tukey's post hoc, $P<$ 0.001 and $P=0.002$, respectively) (Fig. 2a). The $\mathrm{pH}$ of dryland soil samples $(6.3 \pm 1.3)$ was lower than those of ponds and paddy soils (Tukey's post hoc, $P=0.02$ and $P=0.24$, respectively) (Fig. 2b). No significant difference on $\mathrm{NO}_{2}{ }^{-}$concentrations was observed among different samples (0.1 - $0.6 \mathrm{mg} / \mathrm{kg}$, ANOVA, $P=0.11)$ (Fig. $2 \mathrm{c})$. TN and TP $(2.8 \pm 1.2$ and $0.5 \pm$ 
$0.3 \mathrm{~g} / \mathrm{kg}$ respectively) showed little noticeable difference in this study (ANOVA, $P=0.42$ and $P$ $=0.11$, respectively) (Fig. 2g-h).

Fig. 2 Physicochemical properties of sediment and soil samples. (a) Moisture content, (b) pH, (c) $\mathrm{NO}_{2}^{-}$, (d) $\mathrm{NH}_{4}^{+}$, (e) $\mathrm{NO}_{3}^{-}$, (f) Dissolved inorganic nitrogen (DIN was composed with $\mathrm{NH}_{4}^{+}$, $\mathrm{NO}_{3}{ }^{-}$and $\mathrm{NO}_{2}{ }^{-}$), (g) TN, (h) TP, (i) TOM. Different lowercase letters above the boxes indicate significant differences between different groups based on one-way ANOVA with Tukey's test $(P$ $<0.05)$

\subsection{Potential denitrification, anammox and $\mathrm{N}_{2} \mathrm{O}$ production rates}

The potential rates of denitrification, anammox and $\mathrm{N}_{2} \mathrm{O}$ production were determined by slurry incubation and isotope pairing technique (Fig. 3). Surface sediments $(0-10 \mathrm{~cm})$ in ponds showed comparable denitrification rates with paddy soils $\left(19.7 \pm 4.5\right.$ versus $\left.19.4 \pm 3.4 \mathrm{nmol} \mathrm{N} \mathrm{g}^{-1} \mathrm{~h}^{-1}\right)$, which were significantly higher than those in deeper sediments $(11.6 \pm 4.4$ and $6.9 \pm 6.4 \mathrm{nmol} \mathrm{N}$ $\mathrm{g}^{-1} \mathrm{~h}^{-1}$ in 10-20 and 20-30 cm, Tukey's post hoc, $P=0.02, P<0.001$, respectively) and dryland soils $\left(7.9 \pm 4.1 \mathrm{nmol} \mathrm{N} \mathrm{g}^{-1} \mathrm{~h}^{-1}\right.$, Tukey's post hoc, $\left.P<0.001\right)$ (Fig. 3a). Anammox rates were one magnitude lower than denitrification rates and showed no significant difference between samples (0.04-1.5 $\mathrm{nmol} \mathrm{N} \mathrm{g}{ }^{-1} \mathrm{~h}^{-1}$, ANOVA, $P=0.16$ ), (Fig. 3b). The relative contributions of anammox to nitrogen removal was higher in sediments of $20-30 \mathrm{~cm}$ depth $(6.2 \pm 4.0 \%)$ and dryland soils $(8.8$ $\pm 4.2 \%$ ) than those of 0-10, 10-20 cm layer sediments and paddy soils (less than 5\%) (Fig. 3c). Denitrification dominated the nitrogen removal process in all samples. Based on the denitrification and anammox reaction rates and soil / sediment density $\left(1.4-1.9 \mathrm{~g} \mathrm{~cm}^{-3}\right)$, the $\mathrm{N}$ loss by surface sediments showed the highest intensity at $206 \pm 51 \mathrm{~g} \mathrm{~N} \mathrm{~m}^{-2} \mathrm{yr}^{-1}$, and dryland soils were discovered with the lowest values at $99 \pm 48 \mathrm{~g} \mathrm{~N} \mathrm{~m}^{-2} \mathrm{yr}^{-1}$. The $\mathrm{N}$ loss intensity of paddy soils $\left(202 \pm 38 \mathrm{~g} \mathrm{~N} \mathrm{~m}^{-2} \mathrm{yr}^{-1}\right)$ were comparable with those in pond surface sediments.

Fig. 3 Potential rates of sediment and soil samples in this study. (a) Potential denitrification rate, (b) potential anammox rate, (c) the contribution of anammox ( $\mathrm{ra} \%$ ), (d) potential $\mathrm{N}_{2}$ production 
rate, (e) potential $\mathrm{N}_{2} \mathrm{O}$ production rate, (f) the ratio of $\left(\mathrm{N}_{2} \mathrm{O} / \mathrm{N}_{2} \mathrm{O}+\mathrm{N}_{2}\right.$ ). Different lowercase letters above the boxes indicate significant differences between different groups based on oneway ANOVA with Tukey's test $(P<0.05)$

The surface sediments showed the highest potential $\mathrm{N}_{2}$ production at $13.2 \pm 3.6 \mathrm{nmol} \mathrm{N} \mathrm{g}^{-1}$ $\mathrm{h}^{-1}$, which were comparable to those in paddy soils of $10.0 \pm 0.8 \mathrm{nmol} \mathrm{N} \mathrm{g}{ }^{-1} \mathrm{~h}^{-1}$ (Tukey's post hoc, $P=0.12)$ (Fig. $3 \mathrm{~d})$. The deeper sediments $(10-20$ and $20-30 \mathrm{~cm})$ and dryland soils showed lower potential $\mathrm{N}_{2}$ production rates at $6.6 \pm 2.2,5.0 \pm 2.8$ and $3.1 \pm 1.2 \mathrm{nmol} \mathrm{N} \mathrm{g}^{-1} \mathrm{~h}^{-1}$ (Tukey's post hoc, $P=0.002, P<0.001$ and $P<0.001$, respectively). The highest $\mathrm{N}_{2} \mathrm{O}$ production rates were observed in paddy soils $\left(9.4 \pm 3.0 \mathrm{nmol} \mathrm{N} \mathrm{g}^{-1} \mathrm{~h}^{-1}\right.$, ANOVA, $\left.P=0.09\right)$ (Fig. 3e). The ratios of $\mathrm{N}_{2} \mathrm{O} /\left(\mathrm{N}_{2} \mathrm{O}+\mathrm{N}_{2}\right)$, which reflected the potential of $\mathrm{N}_{2} \mathrm{O}$ release during nitrogen removal, showed high values up to $54.4 \%$ and $47.6 \%$ in dryland and paddy soils, respectively. In the pond sediments, samples taken at different depths showed little variances (ANOVA, $P=0.22$ ) (Fig. $3 f)$.

\subsection{Abundance of denitrification and anammox bacteria}

Functional genes involved in denitrification and anammox 16S rRNA gene were dertermined with qPCR assays. For nir gene, surface sediments in ponds were discovered with higher nirS gene abundances at $(7 \pm 4) \times 10^{8}$ copies $\mathrm{g}^{-1}$ than deeper sediments $(10-20$ and $20-30 \mathrm{~cm})$ and dryland soils (Tukey's post hoc, $P=0.002, P<0.001$ and $P<0.001$, respectively). The paddy

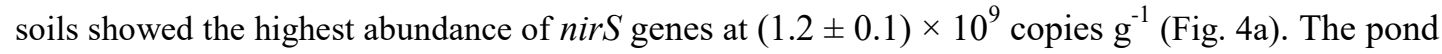
sediments showed the lowest nirK gene abundances from 0.1 to $2.0 \times 10^{8}$ copies $\mathrm{g}^{-1}$ (Fig. 4b) The paddy soils had the highest values of $(5.5 \pm 1.0) \times 10^{8}$ copies $\mathrm{g}^{-1}$ follwed by dryland soils at $(2.7 \pm 1.3) \times 10^{8}$ copies $\mathrm{g}^{-1}$. Moreover, nirS genes were more abundant than $\operatorname{nirK}$ genes in all samples.

Fig. 4 Abundances of nitrogen removal related genes in this study including (a) $\operatorname{nir} S$ gene, (b) $\operatorname{nirK}$ gene, (c) anammox 16S rRNA gene, (d) bacteria 16S rRNA gene, (e) nosZ I gene, (f) nosZ II gene, (g) 
the ratio of nir/nosZ. Different lowercase letters above the boxes indicate significant differences between different groups based on one-way ANOVA with Tukey's test $(P<0.05)$

For $\mathrm{N}_{2} \mathrm{O}$-reducers, the abundances of nos $Z$ II gene were higher than nos $Z$ I gene. The abundances of $\operatorname{nos} Z$ I varied from $8.4 \times 10^{5}$ to $8.3 \times 10^{6}$ copies $^{-1}$ with no noticeable difference between samples (ANOVA, $P<0.01$ ) (Fig. 4e). The nos $Z$ II genes maintained at low abundance $\left(0.1-15.4 \times 10^{7}\right.$ copies $\left.\mathrm{g}^{-1}\right)$ across layers in ponds sediment without significant difference (ANOVA, $P=0.12$ ) (Fig. 4f). The abundance of nos $Z$ II genes in dryland and paddy soils showed high abundance at $(1.9 \pm 0.7) \times 10^{8}$ copies $\mathrm{g}^{-1}$ and $(3.7 \pm 0.9) \times 10^{8}$ copies $\mathrm{g}^{-1}$ than pond sediments (Tukey's post hoc, $P=0.007$ and $P<0.001$, respectively). The ratios of (nirS + nirK)/ ( nosZ I + nosZ II) were above 1 in all samples suggesting a higher abundance of nir genes (Fig. $4 \mathrm{~g})$.

Additionally, the abundance of anammox bacterial 16S rRNA genes was low with no significant difference between samples $\left(8.2 \times 10^{3}\right.$ to $5.8 \times 10^{4}$ copies $\mathrm{g}^{-1}$, ANOVA, $\left.P=0.06\right)$

(Fig. 4c). Total bacteria 16S rRNA gene numbers $\left(0.4-3.6 \times 10^{10}\right.$ copies $\left.\mathrm{g}^{-1}\right)$ showed highest abundance (ANOVA, $P<0.001$ ) in the surface sediment samples of ponds. (Fig. 4d).

\subsection{Diversity and composition of denitrification and anammox}

\section{bacteria}

The diversity of the key players in nitrogen removal was determined by amplicon sequencing. For nirS, after filtering the 330,501 raw sequences, 165,568 high-quality sequences were respectively).

Fig. 5 (a) Principal co-ordinates analysis (PCoA) of the nirS gene based on Bray-Curtis distances. (b) Relative abundance of nirS-type denitrifiers at the genus level 
The most abundant 50 OTUs, covering $62.5 \%$ of the $\operatorname{nir} S$ sequences, were all affiliated to Proteobacteria. At the genus level, significant differences were discovered in pond sediments, paddy, and dryland soils. Most sequences identified in pond sediments were affiliated to Azoarcus $(59.45 \pm 5.14 \%)$, and followed by Steroidobacter and Dechloromonas. Rhodanobacter was the dominant genus in dryland soils $(58.1 \pm 16.2 \%)$, and Steroidobacter had the highest relative abundance in paddy soils $(44.1 \pm 2.1 \%)$ (Fig $5 \mathrm{~b}$ and $\mathrm{S} 3 \mathrm{a})$. The PCoA showed that the first two axes explained $50.4 \%$ of $\operatorname{nirS}$ community (Fig 5a). The nirS community showed a significant separation between samples of sediment, dryland soil and paddy soil (ANOSIM, $P=$ 0.01), and low variance was discovered in different layers of pond sediments. According to the CCA analysis, $\mathrm{pH}, \mathrm{NH}_{4}{ }^{+}$and DIN were the main factors significantly related to nirS community structure $(P<0.01$, Fig S6a).

After filtering the 343,183 raw anammox 16S rRNA sequences, a total of 171,330 highquality sequences were clustered into 204 OTUs. The Shannon diversity indexes of pond sediments, paddy soils and dryland soils (Table S4 and Fig S2b) were 0.69-2.94, 1.33-1.75 and 0.59-1.91, and little significant difference was observed between samples (ANOVA, $p=0.17$ ). The pond sediments showed the highest Chaol richness at 59.86-104.73 versus $41.00-77.10$ in paddy soil and 41.80-86.19 in dryland soil (Tukey's post hoc, $p=0.002$ and $p=0.01$, respectively).

The dominant OTUs (30 OTUs, covering $94.2 \%$ of the sequences) were all affiliated to Planctomycetes. Only 9 OTUs were affiliated to anammox genus $\mathrm{Ca}$. Brocadia, and other sequences were divided into two unknown clusters (cluster 1 and 2) (Fig. S3b). Cluster 1 was close to the uncultured bacterium from freshwater wetland and lake sediments, and cluster 2 was more similar with samples from South China Sea sediment and paddy soil. In pond sediments, less sequences were affiliated with anammox bacteria $(12.4 \pm 1.9 \%)$, while sequences in dryland and paddy soils were dominated by genus $\mathrm{Ca}$. Brocadia ( $82.7 \%$ and $67.2 \%$, respectively) (Fig. S4). The distribution of the bacteria for all samples were further analyzed by NMDS (Fig S5, explained by $80.81 \%$ of the variances). The community was significantly separated into two groups (pond sediments versus paddy/dryland soils, ANOSIM, $P=0.002$ ). The community of sediment in different depths showed little variation. The CCA analysis indicated that TOM and 


\subsection{Drivers of nitrogen removal}

PLS-PM analysis was used to access the direct and indirect effect of a single factor or the combination of interacting factors on potential nitrogen removal rates (Fig 6). Moisture content and $\mathrm{pH}$ showed significantly positive effects on nutrients (TN, TP and TOM), DIN and denitrifier commnity (coefficients $=0.665,0.741$ and 0.546 respectively; $P<0.001$ ). DIN had a negtive effect on denitrifiers gene abundance (coefficients $=-0.552, P<0.05$ ). By contrast, DIN showed positive effects on denitrifier community composition (coefficients $=0.427, P<0.001$ ) and potential nitrogen removal rates (coefficients $=0.616, P<0.05$ ). Denitrifiers gene abundances also had a significantly positive effect on potential nitrogen removal rates (coefficients $=0.483$, $P<0.05)$.

Fig. 6 Directed graph of the Partial Least Squares Path Model (PLS-PM). Each box represents an observed variables or latent variables. Path coefficients are calculated after 1000 bootstraps. Coefficients differ significantly from 0 are indicated by $* P \leq 0.05,{ }^{* *} P \leq 0.01, * * * P \leq 0.001$. The model is assessed using the Goodness of Fit statistic, a measure of the overall prediction performance (The GoF index is 0.58 )

\section{Discussion}

\subsection{Ponds as nutrient pool of the watershed}

Ponds are often overlooked freshwater ecosystems due to their relatively small area (ertli 2018). However, the ponds appear to be a nutrient pool within the studied agricultural watershed. The dissolved inorganic nitrogen (DIN) in pond sediments (up to $21.9 \mathrm{mg} / \mathrm{kg}$ ) was significantly higher than those of surronding agricultural soils $(6.0-9.3 \mathrm{mg} / \mathrm{kg}$ in surface soil), and so was the TOM which was $105.0 \mathrm{~g} / \mathrm{kg}$ in surface sediments versus $56.5-76.5 \mathrm{~g} / \mathrm{kg}$ in agricultural soils. Taking into consideration the respective areas of ponds and agricultural fields, the ponds may contain $18.5 \%$ of the total DIN and $14.9 \%$ of the TOM, while only covering $7.1 \%$ of the total 
area in the targetted research region.

Addtionally, the DIN in ponds was at a high level in comparison with other types of waterbodies, such as freshwater rivers (4.75-7.80 mg/kg) (Arce et al. 2018; Kim et al. 2016), lakes(0.01-8.54 mg/kg) (Cao et al. 2009; Zimmer-Faust et al. 2017) and reservoirs (1.5-11.55

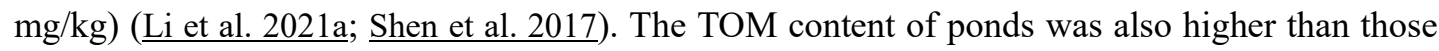
of freshwater rivers (6.2-85.0 g/kg) (Mata et al. 2020; Pisani et al. 2013), lakes (32-79 g/kg) ( al. 2017; Hickey \& Gibbs 2009) and reservoirs (13.8-61.8 g/kg) (Han et al. 2020; Trojanowska \& Izydorczyk 2010). The ponds were mostly located close to human settlements, and thus were apt to receive pollution discharged from daily life and farming (Aguilar et al. 2012). The high content of TOM and high ratio of $\mathrm{NH}_{4}{ }^{+}$in DIN (93.3\%-98.3\%) also suggested that the nutrients in ponds probably originated from human activities (Li et al. 2013).

\subsection{High rate of nitrogen removal in ponds}

The nitrogen removal that occurred in pond sediment is a considerable rapid process when comparing with other agricultural units. The rates of nitrogen removal (denitrification plus anammox) in pond surface sediments (12.4-25.5 $\left.\mathrm{nmol} \mathrm{N} \mathrm{g}^{-1} \mathrm{~h}^{-1}\right)$ were 2-9 times higher than those in dryland soils (3.0-15.7 $\mathrm{nmol} \mathrm{N} \mathrm{g}{ }^{-1} \mathrm{~h}^{-1}$ ), and were comparable with those of paddy field soils (16.1-24.5 $\left.\mathrm{nmol} \mathrm{N} \mathrm{g}{ }^{-1} \mathrm{~h}^{-1}\right)$. The nitrogen removal rates were also higher than those in estuaries influenced by extensive human activity (3.1-7.5 $\left.\mathrm{nmol} \mathrm{N} \mathrm{g}^{-1} \mathrm{~h}^{-1}\right)$ (Li et al. 2020), rivers (0.05-1.14 nmol $\mathrm{N} \mathrm{g}^{-1} \mathrm{~h}^{-1}$ ) (Zhang et al. 2021b), wetlands (0.30-4.12 $\left.\mathrm{nmol} \mathrm{N} \mathrm{g}^{-1} \mathrm{~h}^{-1}\right)$ (Coban et al. 2015; Gao et al. 2016; Wang et al. 2019b). The high rates of nitrogen removal in ponds were largely caused by the nutrient enrichment which was proven to have a positive effect on denitrification, mineralization processes (Doroski et al. 2019) and the overall geochemical dynamics ( $\underline{\text { Cheng \& }}$ Basu 2017). It was further confirmed using PLS-PM and Pearson correlation analysis that the DIN and TOM both showed positive correlations with the nitrogen removal rates (Fig 6 and S1).

In this study, denitrification dominated (>90\%) the nitrogen removal process in ponds, which was consistent with data from several natural habitats (tidal rivers, marine, reservoirs) (McCarthy et al. 2015; Tall et al. 2011; Zhou et al. 2019). In previous studies, the high proportion of denitrification is often associated with high level of organic matter or carbon content 

the physiology of many denitrifiers consuming organic matter in their metabolism (Baker et al. 2000; Jones Jr 1995). It was also identified in this study that lower denitrification rates were detected in deeper sediments and dryland soils with lower organic matter content. Pearson correlation analysis further confirmed the significant correlation $(\mathrm{r}=0.437, P<0.05)$ between TOM and denitrification rates (Fig S1). The DIN (mostly $\mathrm{NH}_{4}^{+}$) also had a positive effect (coefficients $=0.616, P<0.05)$ on denitrification rates $($ Fig 6$)$. In addition, a significant negative correlation between $\mathrm{NO}_{3}^{-}$and denitrification rates was observed, which was different from previous studies (Bruland et al. 2006; Hunt et al. 2004). It was probably because the denitrification rates in dryland soils, which had higher $\mathrm{NO}_{3}{ }^{-}$concentrations, were significantly lower than those of pond sediments and paddy soils. The $\mathrm{NO}_{3}{ }^{-}$and TOM act as electron acceptor and donor respectively, to regulate the denitrification process. TOM is more decisive compared to $\mathrm{NO}_{3}{ }^{-}$in freshwater ecosystems (Burgin et al. 2010; Hill \& Cardaci 2004). Hence, the higher denitrification rates in the sediments were more likely to be regulated by the high content of TOM in sediment. In general, the human nutrients input (DIN and TOM) not only turns the ponds into a nutrient pool, but also shapes the pond into a hotspot of microbial nitrogen removal.

By contrast, the anammox process only contributed $4.3 \pm 3.0 \%$ of nitrogen removal in ponds, which was consistent with the levels reported in other natural ecosystems (river estuaries, inland rivers) (Dale et al. 2009; Kessler et al. 2018; Zhou et al. 2014). However, anammox bacteria were also shown to be widely abundant and responsible for up to $41 \%$ of the total $\mathrm{N}$ loss in other areas such as estuaries (Dalsgaard et al. 2003), paddy fields (Shen et al. 2014; Zhu et al.

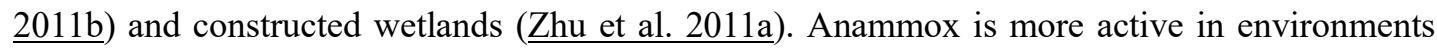
where $\mathrm{NO}_{3}{ }^{-}$is readily available (Engström et al. 2005; Trimmer et al. 2003). However, anammox as an autotrophic process is usually more competitive than denitrification in low organic carbon environments (Plummer et al. 2015). Thus, in surface sediments and paddy soils, which had higher organic matter, anammox was responsible for only $5 \%$ of the nitrogen removal. By contrast, higher anammox contributions (up to $13.4 \%$ of total nitrogen removal) were detected in dryland soils with higher content of $\mathrm{NO}_{3}{ }^{-}$and lower content of TOM. ${ }^{3}$ ), an estimated total loss by the combination of denitrification and anammox processes was 47.8 
and $25.0 \mathrm{t} \mathrm{N} \mathrm{yr}^{-1}$ in dryland and paddy soils, while the pond surface sediments in the study area contributed $14.0 \mathrm{t} \mathrm{N} \mathrm{yr}^{-1}$. Thus, $16.2 \%$ of the nitrogen was removed from the ponds with only $7.12 \%$ of the area. The pond is a neglected hotspot for nitrogen removal in agricultural watershed.

Strong potentials of $\mathrm{N}_{2} \mathrm{O}$ production appeared along with the nitrogen removal in ponds. The $\mathrm{N}_{2} \mathrm{O}$ production rates from pond sediments $\left(6.5 \pm 2.2 \mathrm{nmol} \mathrm{N} \mathrm{g}^{-1} \mathrm{~h}^{-1}\right)$ were higher than many habitats like sea $\left(0-0.09 \mathrm{nmol} \mathrm{N} \mathrm{g} \mathrm{g}^{-1} \mathrm{~h}^{-1}\right)$, estuary $\left(0.03-3.40 \mathrm{nmol} \mathrm{N} \mathrm{g} \mathrm{g}^{-1}\right)$, riparian zones $(0$ $\left.0.04 \mathrm{nmol} \mathrm{N} \mathrm{g} \mathrm{h}^{-1}\right)$ and wetlands $\left(0-1.60 \mathrm{nmol} \mathrm{N} \mathrm{g}^{-1} \mathrm{~h}^{-1}\right)$ (David et al. 2013; $\underline{\text { Li et al. 2021b }}$ iㅡ et al. 2017; Liu et al. 2016; Teixeira et al. 2010). The $\mathrm{N}_{2} \mathrm{O} /\left(\mathrm{N}_{2} \mathrm{O}+\mathrm{N}_{2}\right)$ percentages in pond sediments $(34.2 \pm 13.2 \%)$ were comparable or higher than those of a nitrogen-enriched subtropical estuaries and stormwater ponds (3.38-51.00\%) (Blaszczak et al. 2018; Li et al. 2021b; Su et al. 2021). Despite the high rates of denitrification in ponds, the terminal product of nitrogen removal in pond sediment was more likely to be $\mathrm{N}_{2}$ compared to dryland soil $\left(\mathrm{N}_{2} \mathrm{O}\right.$ / $\left(\mathrm{N}_{2} \mathrm{O}+\mathrm{N}_{2}\right)$ up to $\left.86.8 \%\right)$. Previous study demonstrated that the ratio of $\mathrm{N}_{2} \mathrm{O} /\left(\mathrm{N}_{2} \mathrm{O}+\mathrm{N}_{2}\right)$ was negatively correlated with $\mathrm{pH}$ ( $\underline{\mathrm{Samad}}$ et al. 2016) , matching the result of Pearson correlation analysis in our study $(\mathrm{r}=-0.558, P<0.001)$. Under lower $\mathrm{pH}(<7.0)$ conditions the $\operatorname{nos} Z$ genes (particularly nos Z II genes) and activity of the $\mathrm{N}_{2} \mathrm{O}$ reductase may be restrained, which would

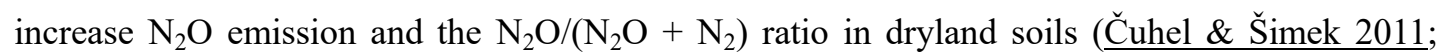
Jones et al. 2014; Pan et al. 2012). Thus, more than half of the $\mathrm{N}_{2} \mathrm{O}$ was emitted as an intermediate product of denitrification processes in dryland soils.

\subsection{Contributors to microbial nitrogen removal}

The high abundance of nirS, nirK, nosZ I and nosZ II genes also supported that denitrifiers were the main contributors to nitrogen removal in ponds, in which these denitrifier gene abundances were 2-5 orders of magnitude higher than those of anammox bacteria. Despite of the frequent exchange of water/soil between ponds and surrounding agricultural fields, the denitrification community in pond sediments, which was mainly composed by genus Azoarcus $(59.5 \pm 21.0 \%)$, was significantly different from that in the surrounding agricultural soils. By contrast, the denitrification community was more similar with those reported in other freshwater ecosystems 
(i.e. lake and river sediments) (Hong et al. 2020; Kim et al. 2011; Zhang et al. 2021a). Hence, it could be concluded that environmental properties like $\mathrm{pH}$, DIN and TOM rather than geological distance were stronger determinants for the community composition of denitrifier in ponds.

The nirS and $\operatorname{nirK}$ genes were detected in high copy numbers in pond surface sediments $\left((7.2 \pm 4.0) \times 10^{8}\right.$ and $(1.2 \pm 0.6) \times 10^{8}$ copies $\mathrm{g}^{-1}$, nir $S$ and nirK respectively), being higher than those reported for marine (Lee \& Francis 2017; Lindemann et al. 2016; Zheng et al. 2021) and freshwater sediments ( $\underline{\text { Jin et al. 2020; }}$ Wang et al. 2019a; Zhu et al. 2018). This suggested extensive denitrification processes in ponds. It was noted that $\operatorname{nir} S$ genes were more abundant than $\operatorname{nirK}$ genes in pond sediments while nirK genes dominated over nirS gene in dryland soils. This is consistent with the properties of nirK type denitrifiers which prefer high $\mathrm{DO}$ and $\mathrm{NO}_{3}^{-}$ (Desnues et al. 2007; Knapp et al. 2009). It was reported that a higher frequency of cooccurrence of nos $Z$ with nirS than with $\operatorname{nirK}$ was reported before, suggesting that nirS type denitrifiers are more likely to perform complete denitrification (Clark et al. 2012; Hallin et al. 2018). Taken this into account, our results would point to lower production of $\mathrm{N}_{2} \mathrm{O}$ in the ponds compared to dryland soils and this supports the rate measurements.

In this study, the abundance of $\operatorname{nos} Z$ II gene $\left(10^{7}-10^{9}\right.$ copies $\left.\mathrm{g}^{-1}\right)$ was greater than that of the nos $Z$ I gene $\left(10^{5}-10^{7}\right.$ copies $\left.\mathrm{g}^{-1}\right)$, and similar results were found in other terrestrial ecosystems with the ratio of 1.5-10 (Jones et al. 2013; $\underline{\text { Juhanson et al. 2017 }}$ Pascazio et al. 2018; $\underline{\mathrm{Su} \text { et al. }}$ 2021; Tsiknia et al. 2015). It was reported that nos Z II played a greater role in reducing $\mathrm{N}_{2} \mathrm{O}$ emission in terrestrial habitats ( abundance together with high $\mathrm{N}_{2} \mathrm{O}$ production potential $\left(\mathrm{N}_{2} \mathrm{O} /\left(\mathrm{N}_{2} \mathrm{O}+\mathrm{N}_{2}\right)\right)$ were observed in dryland soils in this study. It was probably because the activity of $\mathrm{N}_{2} \mathrm{O}$ reductase was restrained

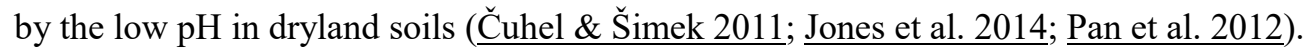

The nir/nos $Z$ ratio had been widely used as indicator of $\mathrm{N}_{2} \mathrm{O}$ production potential observed with positive correlation (Domeignoz-Horta et al. 2015; Saarenheimo et al. 2015; Zhao et al. 2020). Nevertheless, we observed a negative correlation between the nir/nos $Z$ and $\mathrm{N}_{2} \mathrm{O} /\left(\mathrm{N}_{2} \mathrm{O}+\right.$ $\left.\mathrm{N}_{2}\right)$ ratio in the pond sediments $(\mathrm{r}=-0.452, P<0.05)$, which coincided with previous studies (Linton et al. 2020; Mafa-Attoye et al. 2020). These results implied that the nir/nos $Z$ ratio only is not a good indicator for $\mathrm{N}_{2} \mathrm{O}$ production in natural habitats. 


\section{Conclusions}

This study investigated the nutrients distribution, microbial nitrogen removal capacities and microbial key players in artificial ponds, dryland, and paddy soils in an agricultural watershed. The following conclusions can be drawn from the results:

- The ponds sediment had significantly higher DIN and TOM content comparing with those in soil of dryland and paddy fields, which evidenced that ponds acted as a nutrients pool in the agricultural watershed.

- High rates of microbial nitrogen removal make the ponds a hotspot of nitrogen removal with denitrification as the absolutely dominant ( $>90 \%$ ) pathway. It was estimated that about $16 \%$ of nitrogen was removed in ponds covering only $7 \%$ of the area in the watershed. High potential of $\mathrm{N}_{2} \mathrm{O}$ production occurred in ponds coinciding with the rapid nitrogen removal.

- The nir genes were always more abundant than nos $Z$ genes. The nir $S$ gene was more abundant under flooded conditions, while nirK gene prefers higher DO and $\mathrm{NO}_{3}^{-}$in drylands. The nitrogen removal bacterial communities showed significant differences between sediment and soil samples.

\section{Declaration of competing interest}

The authors declare that they have no known competing financial interests or personal relationships that could have appeared to influence the work reported in this paper.

\section{Acknowledgements}

This work was financially supported by the National Natural Science Foundation of China (grant numbers 41977153, 51908145, 31870100). 
Data collected and used in this manuscript are available in supplementary material file.

\section{References}

Aguilar CA, Montalvo C, Rodríguez L, Cerón JG, Cerón RM (2012) American oyster (Crassostrea virginica) and sediments as a coastal zone pollution monitor by heavy metals. Int. J. Environ. Sci. Technol. 9(4): 579-586. 10.1007/s13762-012-0078-y

Apha A (1998) Standard methods for the examination of water and wastewater, 20. Washington, DC: American Public Health Association

Arce MI, von Schiller D, Bengtsson MM, Hinze C, Jung H, Alves RJE, Urich T, Singer G (2018) Drying and Rainfall Shape the Structure and Functioning of Nitrifying Microbial Communities in Riverbed Sediments. Front. Microbiol. 9: 2794. 10.3389/fmicb.2018.02794

Baker MA, Valett HM, Dahm CN (2000) Organic carbon supply and metabolism in a shallow groundwater ecosystem. Ecology 81(11): 3133-3148. 10.1890/00129658(2000)081[3133:OCSAMI]2.0.CO;2

Ballantine K, Schneider R (2009) Fifty-five years of soil development in restored freshwater depressional wetlands. Ecol. Appl. 19(6): 1467-1480. 10.1890/07-0588.1

Blaszczak JR, Steele MK, Badgley BD, Heffernan JB, Hobbie SE, Morse JL, Rivers EN, Hall SJ, Neill C, Pataki DE, Groffman PM, Bernhardt ES (2018) Sediment chemistry of urban stormwater ponds and controls on denitrification. Ecosphere 9(6): e02318. 10.1002/ecs2.2318

Boix D, Kneitel J, Robson BJ, Duchet C, Zúñiga L, Day J, Gascón S, Sala J, Quintana XD, Blaustein L (2016) Invertebrates of Freshwater Temporary Ponds in Mediterranean Climates. In: Batzer D \& Boix D (eds) Invertebrates in Freshwater Wetlands: An International Perspective on their Ecology. Springer International Publishing, Cham. p 141-189

Brazier RE, Puttock A, Graham HA, Auster RE, Davies KH, Brown CML (2021) Beaver: Nature's ecosystem engineers. WIREs Water 8(1): e1494. 10.1002/wat2.1494

Bruesewitz DA, Hamilton DP, Schipper LA (2011) Denitrification Potential in Lake Sediment Increases Across a Gradient of Catchment Agriculture. Ecosystems 14(3): 341-352. 10.1007/s10021-011-9413-2

Bruland GL, Richardson CJ, Whalen SC (2006) Spatial variability of denitrification potential and related soil properties in created, restored, and paired natural wetlands. Wetlands 26(4): 10421056. 10.1672/0277-5212(2006)26[1042:SVODPA]2.0.CO;2

Brunet CE, Gemrich ERC, Biedermann S, Jacobson PJ, Schilling KE, Jones CS, Graham AM (2021) Nutrient capture in an Iowa farm pond: Insights from high-frequency observations. J. Environ. Manag. 299: 113647. 10.1016/j.jenvman.2021.113647

Burgin AJ, Groffman PM, Lewis DN (2010) Factors Regulating Denitrification in a Riparian Wetland. Soil Sci. Soc. Am. J. 74(5): 1826-1833. 10.2136/sssaj2009.0463

Cai M, Ye F, Wu J, Wu Q, Wang Y, Hong Y (2020) Bias of marker genes in PCR of anammox bacteria in natural habitats. PLoS ONE 15(10): e0239736. 10.1371/journal.pone.0239736 
Cao T, Xie P, Ni L, Zhang M, Xu J (2009) Carbon and nitrogen metabolism of an eutrophication tolerative macrophyte, Potamogeton crispus, under $\mathrm{NH}_{4}{ }^{+}$stress and low light availability. Environ. Exp. Bot. 66(1): 74-78. 10.1016/j.envexpbot.2008.10.004

Caporaso JG, Kuczynski J, Stombaugh J, Bittinger K, Bushman FD, Costello EK, Fierer N, Peña AG, Goodrich JK, Gordon JI, Huttley GA, Kelley ST, Knights D, Koenig JE, Ley RE, Lozupone CA, McDonald D, Muegge BD, Pirrung M, Reeder J, Sevinsky JR, Turnbaugh PJ, Walters WA, Widmann J, Yatsunenko T, Zaneveld J, Knight R (2010) QIIME allows analysis of highthroughput community sequencing data. Nat. Meth. 7(5): 335-336. 10.1038/nmeth.f.303

Capps KA, Rancatti R, Tomczyk N, Parr TB, Calhoun AJ, Hunter M (2014) Biogeochemical hotspots in forested landscapes: the role of vernal pools in denitrification and organic matter processing. Ecosystems 17(8): 1455-1468. 10.1007/s10021-014-9807-z

Chen C, Meurk CD, Jia Z, Lv M, Wu S, Jia J (2017) Incorporating landscape connectivity into household pond configuration in a hilly agricultural landscape. Landsc. Ecol. Eng. 13(1): 189204. 10.1007/s11355-016-0317-3

Chen W, He B, Nover D, Lu H, Liu J, Sun W, Chen W (2019) Farm ponds in southern China: Challenges and solutions for conserving a neglected wetland ecosystem. Sci. Total Environ. 659: 1322-1334. 10.1016/j.scitotenv.2018.12.394

Cheng FY, Basu NB (2017) Biogeochemical hotspots: Role of small water bodies in landscape nutrient processing. Water Resour. Res. 53(6): 5038-5056. 10.1002/2016WR020102

Clark IM, Buchkina N, Jhurreea D, Goulding KW, Hirsch PR (2012) Impacts of nitrogen application rates on the activity and diversity of denitrifying bacteria in the Broadbalk Wheat Experiment. Philosophical Transactions of the Royal Society B: Biological Sciences 367(1593): 1235-1244. 10.1098/rstb.2011.0314

Coban O, Kuschk P, Kappelmeyer U, Spott O, Martienssen M, Jetten MSM, Knoeller K (2015) Nitrogen transforming community in a horizontal subsurface-flow constructed wetland. Water Res. 74: 203-212. 10.1016/j.watres.2015.02.018

Čuhel J, Šimek M (2011) Proximal and distal control by $\mathrm{pH}$ of denitrification rate in a pasture soil. Agric., Ecosyst. Environ. 141(1): 230-233. 10.1016/j.agee.2011.02.016

Dahl TE (2014) Status and trends of prairie wetlands in the United States 1997 to 2009. US Fish and Wildlife Service

Dale OR, Tobias CR, Song B (2009) Biogeographical distribution of diverse anaerobic ammonium oxidizing (anammox) bacteria in Cape Fear River Estuary. Environ. Microbiol. 11(5): 11941207. 10.1111/j.1462-2920.2008.01850.x

Dalsgaard T, Canfield DE, Petersen J, Thamdrup B, Acuña-González J (2003) $\mathrm{N}_{2}$ production by the anammox reaction in the anoxic water column of Golfo Dulce, Costa Rica. Nature 422(6932): 606-608. 10.1038/nature01526

David C-G, Diana E M, Germán T, David B, Laurent P, Eulogio J B (2013) Spatial distribution of Ncycling microbial communities showed complex patterns in constructed wetland sediments. FEMS Microbiol. Ecol. 83(2): 340-351. 10.1111/j.1574-6941.2012.01479.x

Desnues C, Michotey VD, Wieland A, Zhizang C, Fourçans A, Duran R, Bonin PC (2007) Seasonal and diel distributions of denitrifying and bacterial communities in a hypersaline microbial mat (Camargue, France). Water Res. 41(15): 3407-3419. 10.1016/j.watres.2007.04.018

Domeignoz-Horta LA, Spor A, Bru D, Breuil M-C, Bizouard F, Léonard J, Philippot L (2015) The diversity of the $\mathrm{N}_{2} \mathrm{O}$ reducers matters for the $\mathrm{N}_{2} \mathrm{O}: \mathrm{N}_{2}$ denitrification end-product ratio across an 
annual and a perennial cropping system. Front. Microbiol. 6: 971-971. 10.3389/fmicb.2015.00971

Doroski AA, Helton AM, Vadas TM (2019) Denitrification Potential and Carbon Mineralization in Restored and Unrestored Coastal Wetland Soils Across an Urban Landscape. Wetlands 39(4): 895-906. 10.1007/s13157-019-01128-z

Downing JA, Cole JJ, Middelburg JJ, Striegl RG, Duarte CM, Kortelainen P, Prairie YT, Laube KA (2008) Sediment organic carbon burial in agriculturally eutrophic impoundments over the last century. Global Biogeochem. Cycles 22(1): 10.1029/2006GB002854

Downing JA, Prairie YT, Cole JJ, Duarte CM, Tranvik LJ, Striegl RG, McDowell WH, Kortelainen P, Caraco NF, Melack JM, Middelburg JJ (2006) The global abundance and size distribution of lakes, ponds, and impoundments. Limnol. Oceanogr. 51(5): 2388-2397. 10.4319/10.2006.51.5.2388

Engström P, Dalsgaard T, Hulth S, Aller RC (2005) Anaerobic ammonium oxidation by nitrite (anammox): Implications for $\mathrm{N}_{2}$ production in coastal marine sediments. Geochim. Cosmochim. Acta 69(8): 2057-2065. 10.1016/j.gca.2004.09.032

Gao J, Hou L, Zheng Y, Liu M, Yin G, Li X, Lin X, Yu C, Wang R, Jiang X, Sun X (2016) nirSEncoding denitrifier community composition, distribution, and abundance along the coastal wetlands of China. Appl. Microbiol. Biotechnol. 100(19): 8573-8582. 10.1007/s00253-0167659-5

Gu B-W, Lee C-G, Lee T-G, Park S-J (2017) Evaluation of sediment capping with activated carbon and nonwoven fabric mat to interrupt nutrient release from lake sediments. Sci. Total Environ. 599-600: 413-421. 10.1016/j.scitotenv.2017.04.212

Hallin S, Philippot L, Löffler FE, Sanford RA, Jones CM (2018) Genomics and Ecology of Novel $\mathrm{N}_{2} \mathrm{O}$-Reducing Microorganisms. Trends Microbiol. 26(1): 43-55. 10.1016/j.tim.2017.07.003

Han C, Qin Y, Zheng B, Ma Y, Yang C, Liu Z, Zhuang D, Zhao Y (2020) Geochemistry of phosphorus release along transect of sediments from a tributary backwater zone in the Three Gorges Reservoir. Sci. Total Environ. 722: 136964. 10.1016/j.scitotenv.2020.136964

Han P, Gu J-D (2013) More refined diversity of anammox bacteria recovered and distribution in different ecosystems. Appl. Microbiol. Biotechnol. 97(8): 3653-3663. 10.1007/s00253-0134756-6

Harrison JA, Maranger RJ, Alexander RB, Giblin AE, Jacinthe P-A, Mayorga E, Seitzinger SP, Sobota DJ, Wollheim WM (2009) The regional and global significance of nitrogen removal in lakes and reservoirs. Biogeochemistry 93(1): 143-157. 10.1007/s10533-008-9272-x

Hernandez ME, Mitsch WJ (2007) Denitrification in created riverine wetlands: Influence of hydrology and season. Ecol. Eng. 30(1): 78-88. 10.1016/j.ecoleng.2007.01.015

Hickey CW, Gibbs MM (2009) Lake sediment phosphorus release management-Decision support and risk assessment framework. N. Z. J. Mar. Freshw. Res. 43(3): 819-856. $10.1080 / 00288330909510043$

Hill AR, Cardaci M (2004) Denitrification and Organic Carbon Availability in Riparian Wetland Soils and Subsurface Sediments. Soil Sci. Soc. Am. J. 68(1): 320-325. 10.2136/sssaj2004.3200a

Hobbie J (1980) Limnology of tundra ponds, Barrow Alaska Dowden. Hutchinson \& Ross

Holgerson MA, Raymond PA (2016) Large contribution to inland water $\mathrm{CO}_{2}$ and $\mathrm{CH}_{4}$ emissions from very small ponds. Nat. Geosci. 9(3): 222-226. 10.1038/ngeo2654

Hong P, Gong S, Wang C, Shu Y, Wu X, Tian C, Donde OO, Cai P, Wu H, Xiao B (2020) Effects of 
organic carbon consumption on denitrifier community composition and diversity along dissolved oxygen vertical profiles in lake sediment surface. J. Oceanol. Limnol. 38(3): 733-744. $10.1007 / \mathrm{s} 00343-019-9103-\mathrm{z}$

Hou L, Yin G, Liu M, Zhou J, Zheng Y, Gao J, Zong H, Yang Y, Gao L, Tong C (2015) Effects of Sulfamethazine on Denitrification and the Associated $\mathrm{N}_{2} \mathrm{O}$ Release in Estuarine and Coastal Sediments. Environ. Sci. Technol. 49(1): 326-333. 10.1021/es504433r

Hunt PG, Matheny TA, Stone KC (2004) Denitrification in a Coastal Plain Riparian Zone Contiguous to a Heavily Loaded Swine Wastewater Spray Field. J. Environ. Qual. 33(6): 2367-2374. $10.2134 /$ jeq2004.2367

Jetten MSM, Sliekers O, Kuypers M, Dalsgaard T, van Niftrik L, Cirpus I, van de Pas-Schoonen K, Lavik G, Thamdrup B, Le Paslier D, Op den Camp HJM, Hulth S, Nielsen LP, Abma W, Third K, Engström P, Kuenen JG, Jørgensen BB, Canfield DE, Sinninghe Damsté JS, Revsbech NP, Fuerst J, Weissenbach J, Wagner M, Schmidt I, Schmid M, Strous M (2003) Anaerobic ammonium oxidation by marine and freshwater planctomycete-like bacteria. Appl. Microbiol. Biotechnol. 63(2): 107-114. 10.1007/s00253-003-1422-4

Jin W, Cao W, Liang F, Wen Y, Wang F, Dong Z, Song H (2020) Water management impact on denitrifier community and denitrification activity in a paddy soil at different growth stages of rice. Agric. Water Manag. 241: 106354. 10.1016/j.agwat.2020.106354

Jones CM, Graf DRH, Bru D, Philippot L, Hallin S (2013) The unaccounted yet abundant nitrous oxide-reducing microbial community: a potential nitrous oxide sink. ISME J. 7(2): 417-426. 10.1038/ismej.2012.125

Jones CM, Spor A, Brennan FP, Breuil M-C, Bru D, Lemanceau P, Griffiths B, Hallin S, Philippot L (2014) Recently identified microbial guild mediates soil $\mathrm{N}_{2} \mathrm{O}$ sink capacity. Nat. Clim. Change 4(9): 801-805. 10.1038/nclimate2301

Jones Jr JB (1995) Factors controlling hyporheic respiration in a desert stream. Freshw. Biol. 34(1): 91-99. 10.1111/j.1365-2427.1995.tb00426.x

Juhanson J, Hallin S, Söderström M, Stenberg M, Jones CM (2017) Spatial and phyloecological analyses of nos $Z$ genes underscore niche differentiation amongst terrestrial $\mathrm{N}_{2} \mathrm{O}$ reducing communities. Soil Biol. Biochem. 115: 82-91. 10.1016/j.soilbio.2017.08.013

Kartal B, Maalcke WJ, de Almeida NM, Cirpus I, Gloerich J, Geerts W, Op den Camp HJM, Harhangi HR, Janssen-Megens EM, Francoijs K-J, Stunnenberg HG, Keltjens JT, Jetten MSM, Strous M (2011) Molecular mechanism of anaerobic ammonium oxidation. Nature 479(7371): 127-130. 10.1038/nature10453

Kessler AJ, Roberts KL, Bissett A, Cook PLM (2018) Biogeochemical Controls on the Relative Importance of Denitrification and Dissimilatory Nitrate Reduction to Ammonium in Estuaries. Global Biogeochem. Cycles 32(7): 1045-1057. 10.1029/2018GB005908

Kim H, Bae H-S, Reddy KR, Ogram A (2016) Distributions, abundances and activities of microbes associated with the nitrogen cycle in riparian and stream sediments of a river tributary. Water Res. 106: 51-61. 10.1016/j.watres.2016.09.048

Kim O-S, Imhoff JF, Witzel K-P, Junier P (2011) Distribution of denitrifying bacterial communities in the stratified water column and sediment-water interface in two freshwater lakes and the Baltic Sea. Aquat. Ecol. 45(1): 99-112. 10.1007/s10452-010-9335-7

Knapp CW, Dodds WK, Wilson KC, O’Brien JM, Graham DW (2009) Spatial Heterogeneity of Denitrification Genes in a Highly Homogenous Urban Stream. Environ. Sci. Technol. 43(12): 
Kuypers MMM, Marchant HK, Kartal B (2018) The microbial nitrogen-cycling network. Nat. Rev. Microbiol. 16(5): 263-276. 10.1038/nrmicro.2018.9

Lee JA, Francis CA (2017) Spatiotemporal Characterization of San Francisco Bay Denitrifying Communities: a Comparison of nirK and nirS Diversity and Abundance. Microb. Ecol. 73(2): 271-284. 10.1007/s00248-016-0865-y

Li N, Li B, Nie M, Wu J (2020) Effects of exotic Spartina alterniflora on saltmarsh nitrogen removal in the Yangtze River Estuary, China. J. Cleaner Prod. 271: 122557. 10.1016/j.jclepro.2020.122557

Li R, Liu S, Zhang G, Ren J, Zhang J (2013) Biogeochemistry of nutrients in an estuary affected by human activities: The Wanquan River estuary, eastern Hainan Island, China. Cont. Shelf Res. 57: 18-31. 10.1016/j.csr.2012.02.013

Li S, Gang D, Zhao S, Qi W, Liu H (2021a) Response of ammonia oxidation activities to water-level fluctuations in riparian zones in a column experiment. Chemosphere 269: 128702. 10.1016/j.chemosphere.2020.128702

Li X, Qian W, Hou L, Liu M, Chen Z, Tong C (2021b) Human activity intensity controls the relative importance of denitrification and anaerobic ammonium oxidation across subtropical estuaries. CATENA 202: 105260. 10.1016/j.catena.2021.105260

Lin X, Liu M, Hou L, Gao D, Li X, Lu K, Gao J (2017) Nitrogen Losses in Sediments of the East China Sea: Spatiotemporal Variations, Controlling Factors, and Environmental Implications. J. Geophys. Res.: Biogeosci. 122(10): 2699-2715. 10.1002/2017JG004036

Lindemann S, Zarnoch CB, Castignetti D, Hoellein TJ (2016) Effect of Eastern Oysters (Crassostrea virginica) and Seasonality on Nitrite Reductase Gene Abundance (nirS, nirK, nrfA) in an Urban Estuary. Estuaries Coasts 39(1): 218-232. 10.1007/s12237-015-9989-4

Linton NF, Ferrari Machado PV, Deen B, Wagner-Riddle C, Dunfield KE (2020) Long-term diverse rotation alters nitrogen cycling bacterial groups and nitrous oxide emissions after nitrogen fertilization. Soil Biol. Biochem. 149: 107917. 10.1016/j.soilbio.2020.107917

Liu W, Xiong Z, Liu H, Zhang Q, Liu G (2016) Catchment agriculture and local environment affecting the soil denitrification potential and nitrous oxide production of riparian zones in the Han River Basin, China. Agric., Ecosyst. Environ. 216: 147-154. 10.1016/j.agee.2015.10.002

Liu X, Wu J, Hong Y, Jiao L, Li Y, Wang L, Wang Y, Chang X (2020) Nitrogen loss by nirS-type denitrifying bacterial communities in eutrophic coastal sediments. Int. Biodeterior. Biodegrad. 150: 104955. 10.1016/j.ibiod.2020.104955

Lü M, Ma M, Wang Y, Chen C, Chen J, Wu S (2019) Functions of traditional ponds in altering sediment budgets in the hilly area of the Three Gorges Reservoir, China. Sci. Total Environ. 658: 537-549. 10.1016/j.scitotenv.2018.12.017

Lü M, Wu S, Ma M, Huang P, Wen Z, Chen J (2021) Spatial distribution characteristics and influencing factors of small water bodies in China. Submitted

Mafa-Attoye TG, Baskerville MA, Ofosu E, Oelbermann M, Thevathasan NV, Dunfield KE (2020) Riparian land-use systems impact soil microbial communities and nitrous oxide emissions in an agro-ecosystem. Sci. Total Environ. 724: 138148. 10.1016/j.scitotenv.2020.138148

Mata HK, Al Salah DMM, Ngweme GN, Konde JN, Mulaji CK, Kiyombo GM, Poté JW (2020) Toxic metal concentration and ecotoxicity test of sediments from dense populated areas of Congo River, Kinshasa, Democratic Republic of the Congo. Environ. Chem. Ecotoxicol. 2: 83-90. 
10.1016/j.enceco.2020.07.001

McCarthy MJ, Newell SE, Carini SA, Gardner WS (2015) Denitrification Dominates Sediment Nitrogen Removal and Is Enhanced by Bottom-Water Hypoxia in the Northern Gulf of Mexico. Estuaries Coasts 38(6): 2279-2294. 10.1007/s12237-015-9964-0

Mushet DM, McKenna OP, McLean KI (2020) Alternative stable states in inherently unstable systems. Ecol Evol 10(2): 843-850. 10.1002/ece3.5944

Oertli B (2018) Editorial: Freshwater biodiversity conservation: The role of artificial ponds in the $21 \mathrm{st}$ century. Aquatic Conservation: Marine and Freshwater Ecosystems 28(2): 264-269. 10.1002/aqc. 2902

Oertli B, Biggs J, Céréghino R, Grillas P, Joly P, Lachavanne J-B (2005) Conservation and monitoring of pond biodiversity: introduction. Aquatic Conservation: Marine and Freshwater Ecosystems 15(6): 535-540. 10.1002/aqc.752

Pan Y, Ye L, Ni B-J, Yuan Z (2012) Effect of $\mathrm{pH}$ on $\mathrm{N}_{2} \mathrm{O}$ reduction and accumulation during denitrification by methanol utilizing denitrifiers. Water Res. 46(15): 4832-4840. 10.1016/j.watres.2012.06.003

Pascazio S, Crecchio C, Scagliola M, Mininni AN, Dichio B, Xiloyannis C, Sofo A (2018) Microbialbased soil quality indicators in irrigated and rainfed soil portions of Mediterranean olive and peach orchards under sustainable management. Agric. Water Manag. 195: 172-179. 10.1016/j.agwat.2017.10.014

Pisani O, Oros DR, Oyo-Ita OE, Ekpo BO, Jaffé R, Simoneit BRT (2013) Biomarkers in surface sediments from the Cross River and estuary system, SE Nigeria: Assessment of organic matter sources of natural and anthropogenic origins. Appl. Geochem. 31: 239-250. 10.1016/j.apgeochem.2013.01.010

Plummer P, Tobias C, Cady D (2015) Nitrogen reduction pathways in estuarine sediments: Influences of organic carbon and sulfide. J. Geophys. Res.: Biogeosci. 120(10): 1958-1972. 10.1002/2015JG003057

Risgaard-Petersen N, Meyer RL, Schmid M, Jetten MSM, Enrich-Prast A, Rysgaard S, Revsbech NP (2004) Anaerobic ammonium oxidation in an estuarine sediment. Aquat. Microb. Ecol. 36(3): 293-304. 10.3354/ame036293

Saarenheimo J, Rissanen AJ, Arvola L, Nykänen H, Lehmann MF, Tiirola M (2015) Genetic and environmental controls on nitrous oxide accumulation in lakes. In: PLoS ONE. vol 3. p $\mathrm{e} 0121201$

Samad MS, Biswas A, Bakken LR, Clough TJ, de Klein CAM, Richards KG, Lanigan GJ, Morales $\mathrm{SE}$ (2016) Phylogenetic and functional potential links $\mathrm{pH}$ and $\mathrm{N}_{2} \mathrm{O}$ emissions in pasture soils. Sci. Rep. 6(1): 35990. 10.1038/srep35990

Sanchez G, Trinchera L (2012) plspm: Partial Least Squares data analysis methods. R package version $0.2-2$

Schloss Patrick D, Westcott Sarah L, Ryabin T, Hall Justine R, Hartmann M, Hollister Emily B, Lesniewski Ryan A, Oakley Brian B, Parks Donovan H, Robinson Courtney J, Sahl Jason W, Stres B, Thallinger Gerhard G, Van Horn David J, Weber Carolyn F (2009) Introducing mothur: Open-Source, Platform-Independent, Community-Supported Software for Describing and Comparing Microbial Communities. Appl. Environ. Microbiol. 75(23): 7537-7541. 10.1128/AEM.01541-09

Seitzinger S, Harrison JA, Böhlke JK, Bouwman AF, Lowrance R, Peterson B, Tobias C, Drecht GV 
(2006) Denitrification across landscapes and waterscapes: a synthesis. Ecol. Appl. 16(6): 20642090. 1051-0761(2006)016[2064:DALAWA]2.0.CO;2

Seitzinger SP (1988) Denitrification in freshwater and coastal marine ecosystems: Ecological and geochemical significance. Limnol. Oceanogr. 302-724. 10.4319/10.1988.33.4part2.0702

Shen L, Cheng H, Liu X, Li J, Liu Y (2017) Potential role of anammox in nitrogen removal in a freshwater reservoir, Jiulonghu Reservoir (China). Environ. Sci. Pollut. Res. 24(4): 3890-3899. 10.1007/s11356-016-8126-7

Shen L, Liu S, Huang Q, Lian X, He Z, Geng S, Jin R, He Y, Lou L, Xu X, Zheng P, Hu B, Lovell CR (2014) Evidence for the Cooccurrence of Nitrite-Dependent Anaerobic Ammonium and Methane Oxidation Processes in a Flooded Paddy Field. Appl. Environ. Microbiol. 80(24): 7611-7619. 10.1128/AEM.02379-14

Small GE, Finlay JC, McKay RML, Rozmarynowycz MJ, Brovold S, Bullerjahn GS, Spokas K, Sterner RW (2016) Large differences in potential denitrification and sediment microbial communities across the Laurentian great lakes. Biogeochemistry 128(3): 353-368. 10.1007/s10533-016-0212-X

Strous M, Pelletier E, Mangenot S, Rattei T, Lehner A, Taylor MW, Horn M, Daims H, Bartol-Mavel D, Wincker P, Barbe V, Fonknechten N, Vallenet D, Segurens B, Schenowitz-Truong C, Médigue C, Collingro A, Snel B, Dutilh BE, Op den Camp HJM, van der Drift C, Cirpus I, van de PasSchoonen KT, Harhangi HR, van Niftrik L, Schmid M, Keltjens J, van de Vossenberg J, Kartal B, Meier H, Frishman D, Huynen MA, Mewes H-W, Weissenbach J, Jetten MSM, Wagner M, Le Paslier D (2006) Deciphering the evolution and metabolism of an anammox bacterium from a community genome. Nature 440(7085): 790-794. 10.1038/nature04647

Su R, Huang R, Zeng J, Zhao D, He R, Yu Z, Wu QL (2021) Rhizosphere-associated nosZII microbial community of Phragmites australis and its influence on nitrous oxide emissions in two different regions. J. Soils Sediments 21: 3326-3341. 10.1007/s11368-021-02967-2

Tall L, Caraco N, Maranger R (2011) Denitrification hot spots: dominant role of invasive macrophyte Trapa natans in removing nitrogen from a tidal river. Ecol. Appl. 21(8): 3104-3114. 10.1890/110061.1

Teixeira C, Magalhães C, Boaventura RAR, Bordalo AA (2010) Potential rates and environmental controls of denitrification and nitrous oxide production in a temperate urbanized estuary. Mar. Environ. Res. 70(5): 336-342. 10.1016/j.marenvres.2010.07.001

Thamdrup B, Dalsgaard T (2002) Production of $\mathrm{N}_{2}$ through anaerobic ammonium oxidation coupled to nitrate reduction in marine sediments. Appl. Environ. Microbiol. 68(3): 1312-1318. 10.1128/aem.68.3.1312-1318.2002

Trimmer M, Nicholls JC, Deflandre B (2003) Anaerobic ammonium oxidation measured in sediments along the Thames estuary, United Kingdom. Appl. Environ. Microbiol. 69(11): 6447-6454. 10.1128/aem.69.11.6447-6454.2003

Trojanowska AA, Izydorczyk K (2010) Phosphorus Fractions Transformation in Sediments Before and After Cyanobacterial Bloom: Implications for Reduction of Eutrophication Symptoms in Dam Reservoir. Water, Air, Soil Pollut. 211(1): 287-298. 10.1007/s11270-009-0299-y

Tsiknia M, Paranychianakis NV, Varouchakis EA, Nikolaidis NP (2015) Environmental drivers of the distribution of nitrogen functional genes at a watershed scale. FEMS Microbiol. Ecol. 91(6): fiv052. 10.1093/femsec/fiv052 
Verhoeven JTA, Arheimer B, Yin C, Hefting MM (2006) Regional and global concerns over wetlands and water quality. Trends Ecol. Evol. 21(2): 96-103. 10.1016/j.tree.2005.11.015

Wang S, Liu W, Zhao S, Wang C, Zhuang L, Liu L, Wang W, Lu Y, Li F, Zhu G (2019a) Denitrification is the main microbial $\mathrm{N}$ loss pathway on the Qinghai-Tibet Plateau above an elevation of $5000 \mathrm{~m}$. Sci. Total Environ. 696: 133852. 10.1016/j.scitotenv.2019.133852

Wang S, Wang W, Zhao S, Wang X, Hefting MM, Schwark L, Zhu G (2019b) Anammox and denitrification separately dominate microbial N-loss in water saturated and unsaturated soils horizons of riparian zones. Water Res. 162: 139-150. 10.1016/j.watres.2019.06.052

Wang S, Zhang Z (2011) Effects of climate change on water resources in China. Clim. Res. 47(1-2): 77-82. 10.3354/cr00965

Wang Y, Zhu G, Harhangi HR, Zhu B, Jetten MSM, Yin C, Op den Camp HJM (2012) Co-occurrence and distribution of nitrite-dependent anaerobic ammonium and methane-oxidizing bacteria in a paddy soil. FEMS Microbiol. Lett. 336(2): 79-88. 10.1111/j.1574-6968.2012.02654.x

Weiss RF, Price BA (1980) Nitrous oxide solubility in water and seawater. Mar. Chem. 8(4): 347-359. 10.1016/0304-4203(80)90024-9

Wissinger SA, Oertli B, Rosset V (2016) Invertebrate communities of alpine ponds. In: Invertebrates in freshwater wetlands. Springer. p 55-103

Wu J, Hong Y, Guan F, Wang Y, Tan Y, Yue W, Wu M, Bin L, Wang J, Wen J (2016) A rapid and highthroughput microplate spectrophotometric method for field measurement of nitrate in seawater and freshwater. Sci. Rep. 6(1): 20165. 10.1038/srep20165

Wu J, Hong Y, Liu X, Hu Y (2021) Variations in nitrogen removal rates and microbial communities over sediment depth in Daya Bay, China. Environ. Pollut. 286: 117267. 10.1016/j.envpol.2021.117267

Xiao K, Wu J, Li H, Hong Y, Wilson AM, Jiao JJ, Shananan M (2018) Nitrogen fate in a subtropical mangrove swamp: Potential association with seawater-groundwater exchange. Sci. Total Environ. 635: 586-597. 10.1016/j.scitotenv.2018.04.143

Xu X, Liu Y, Singh BP, Yang Q, Zhang Q, Wang H, Xia Z, Di H, Singh BK, Xu J, Li Y (2020) NosZ clade II rather than clade I determine in situ $\mathrm{N}_{2} \mathrm{O}$ emissions with different fertilizer types under simulated climate change and its legacy. Soil Biol. Biochem. 150: 107974. 10.1016/j.soilbio.2020.107974

Xue L, Hou P, Zhang Z, Shen M, Liu F, Yang L (2020) Application of systematic strategy for agricultural non-point source pollution control in Yangtze River basin, China. Agric., Ecosyst. Environ. 304: 107148. 10.1016/j.agee.2020.107148

Yan W, Yin C, Tang H (1998) Nutrient Retention by Multipond Systems: Mechanisms for the Control of Nonpoint Source Pollution. J. Environ. Qual. 27(5): 1009-1017. $10.2134 /$ jeq1998.00472425002700050005x

Ye F, Wang X, Wang Y, Wu S, Wu J, Hong Y (2021) Different pioneer plant species have similar rhizosphere microbial communities. Plant Soil 464(1): 165-181. 10.1007/s11104-021-04952-7

Yergeau E, Kang S, He Z, Zhou J, Kowalchuk GA (2007) Functional microarray analysis of nitrogen and carbon cycling genes across an Antarctic latitudinal transect. ISME J. 1(2): 163-179. 10.1038/ismej.2007.24

Yin C, Zhao M, Jin W, Lan Z (1993) A multi-pond system as a protective zone for the management of lakes in China. Hydrobiologia 251(1): 321-329. 10.1007/BF00007191

Youn Chi H, Pandit A (2012) Estimation of Average Annual Removal Efficiencies of Wet Detention 
Ponds Using Continuous Simulation. J. Hydrol. Eng. 17(11): 1230-1239. 10.1061/(ASCE)HE.1943-5584.0000522

Zhang H, Liu K, Huang T, Li N, Si F, Feng J, Huang X, Miao Y (2021a) Effect of thermal stratification on denitrifying bacterial community in a deep drinking water reservoir. J. Hydrol. 596: 126090. 10.1016/j.jhydrol.2021.126090

Zhang S, Qin W, Bai Y, Zhang Z, Wang J, Gao H, Gu J-D, Xia X (2021b) Linkages between anammox and denitrifying bacterial communities and nitrogen loss rates in high-elevation rivers. Limnol. Oceanogr. 66(3): 765-778. 10.1002/lno.11641

Zhao S, Zhou J, Yuan D, Wang W, Zhou L, Pi Y, Zhu G (2020) NirS-type $\mathrm{N}_{2} \mathrm{O}$-producers and nosZ IItype $\mathrm{N}_{2} \mathrm{O}$-reducers determine the $\mathrm{N}_{2} \mathrm{O}$ emission potential in farmland rhizosphere soils. J. Soils Sediments 20(1): 461-471. 10.1007/s11368-019-02395-3

Zheng Y, Hou L, Zhang Z, Ge J, Li M, Yin G, Han P, Dong H, Liang X, Gao J, Gao D, Liu M (2021) Overlooked contribution of water column to nitrogen removal in estuarine turbidity maximum zone (TMZ). Sci. Total Environ. 788: 147736. 10.1016/j.scitotenv.2021.147736

Zhou S, Borjigin S, Riya S, Terada A, Hosomi M (2014) The relationship between anammox and denitrification in the sediment of an inland river. Sci. Total Environ. 490: 1029-1036. 10.1016/j.scitotenv.2014.05.096

Zhou S, Zhang Y, Huang T, Liu Y, Fang K, Zhang C (2019) Microbial aerobic denitrification dominates nitrogen losses from reservoir ecosystem in the spring of Zhoucun reservoir. Sci. Total Environ. 651: 998-1010. 10.1016/j.scitotenv.2018.09.160

Zhu G, Wang S, Feng X, Fan G, Jetten MSM, Yin C (2011a) Anammox Bacterial Abundance, Biodiversity and Activity in a Constructed Wetland. Environ. Sci. Technol. 45(23): 9951-9958. $10.1021 / \mathrm{es} 202183 \mathrm{w}$

Zhu G, Wang S, Li Y, Zhuang L, Zhao S, Wang C, Kuypers MMM, Jetten MSM, Zhu Y (2018) Microbial pathways for nitrogen loss in an upland soil. Environ. Microbiol. 20(5): 1723-1738. $10.1111 / 1462-2920.14098$

Zhu G, Wang S, Wang Y, Wang C, Risgaard-Petersen N, Jetten MSM, Yin C (2011b) Anaerobic ammonia oxidation in a fertilized paddy soil. The ISME Journal 5(12): 1905-1912. 10.1038/ismej.2011.63

Zimmer-Faust AG, Thulsiraj V, Marambio-Jones C, Cao Y, Griffith JF, Holden PA, Jay JA (2017) Effect of freshwater sediment characteristics on the persistence of fecal indicator bacteria and genetic markers within a Southern California watershed. Water Res. 119: 1-11. 10.1016/j.watres.2017.04.028 
Figures

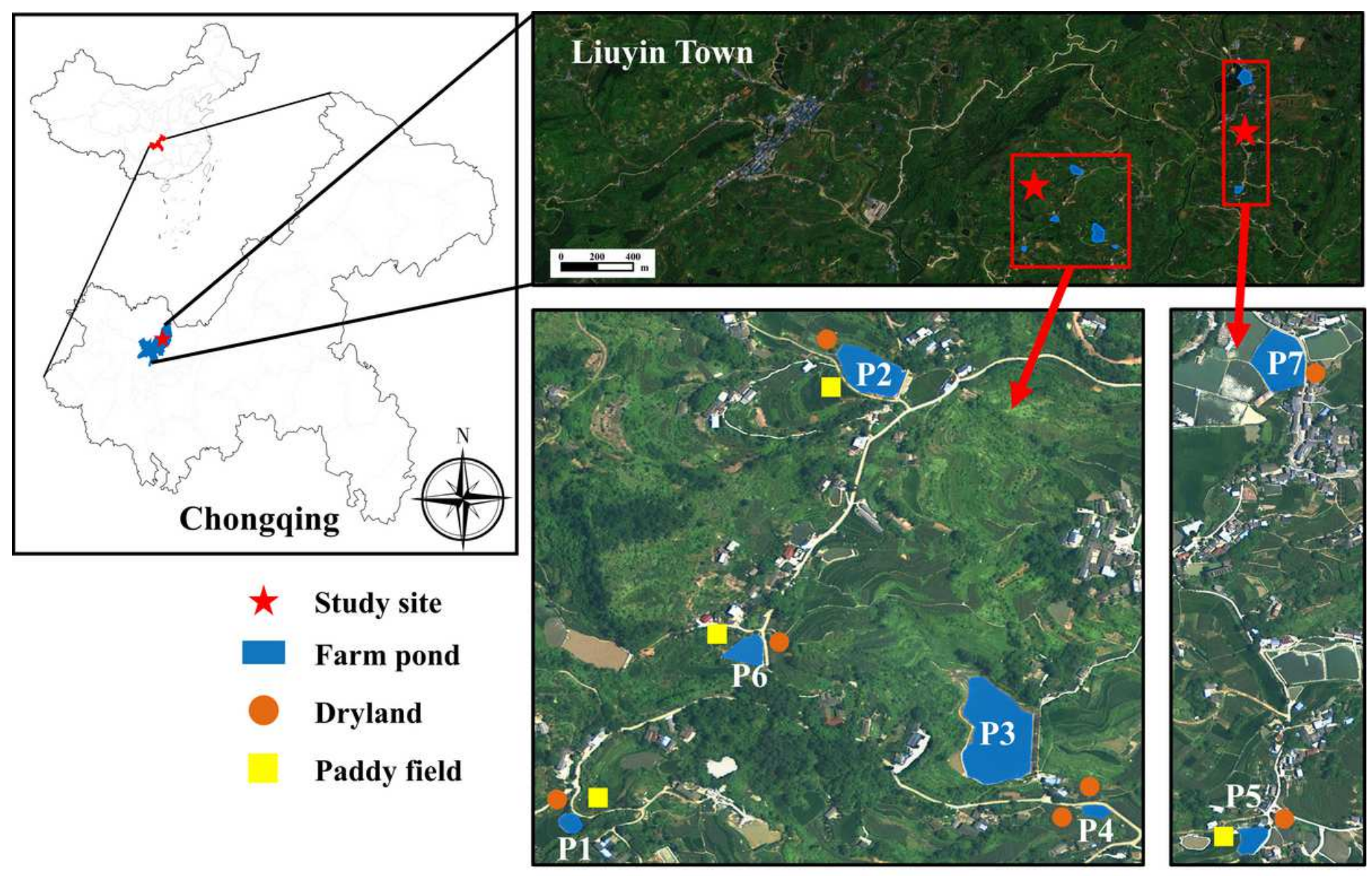

Figure 1

Location and distribution of sampling sites in study area 

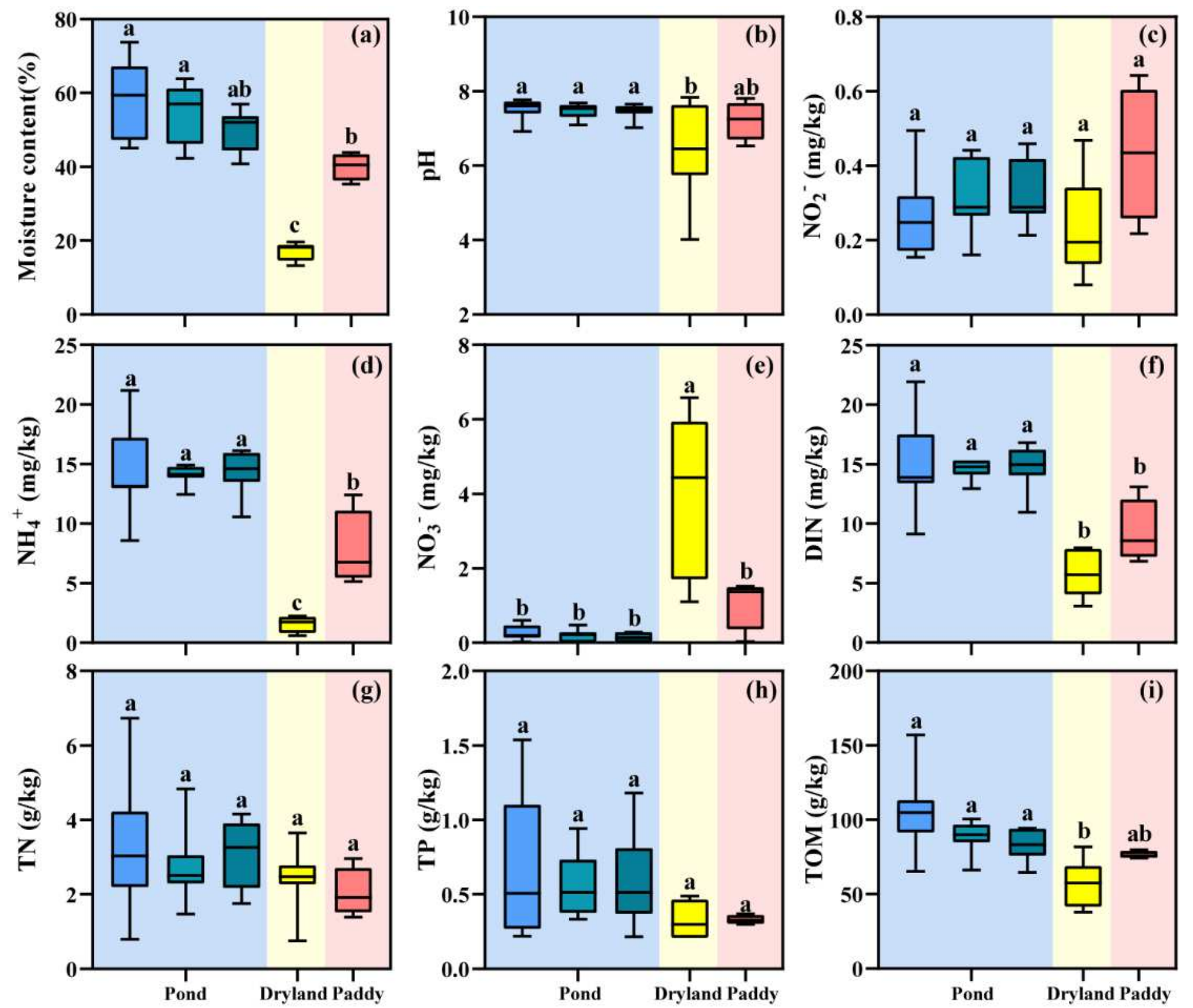

$\square$ P-0-10 cm (n=7) $\square$ P-10-20 cm (n=7) $\square$ P-20-30 cm (n=7) $\square$ Dryland (n=7) $\square$ Paddy soil (n=4)

Figure 2

Physicochemical properties of sediment and soil samples. (a) Moisture content, (b) $\mathrm{pH}$, (c) $\mathrm{NO}_{2}{ }^{-}$, (d) $\mathrm{NH}_{4}{ }^{+}$, (e) $\mathrm{NO}_{3}{ }^{-}$, (f) Dissolved inorganic nitrogen (DIN was composed with $\mathrm{NH}_{4}{ }^{+}, \mathrm{NO}_{3}{ }^{-}$and $\mathrm{NO}_{2}{ }^{-}$), (g) $\mathrm{TN}$, (h) TP, (i) TOM. Different lowercase letters above the boxes indicate significant differences between different groups based on one-way ANOVA with Tukey's test $(P<0.05)$ 

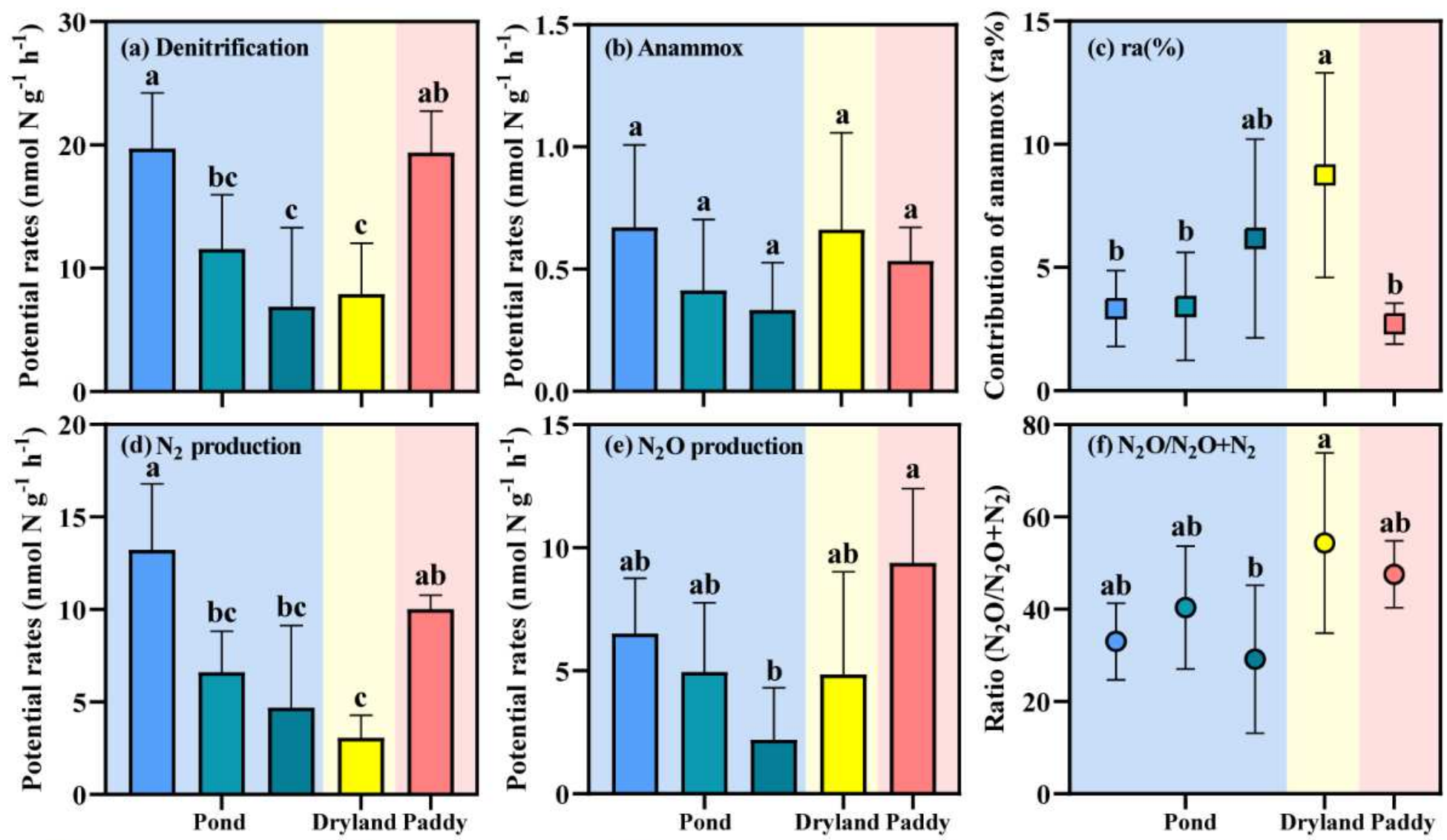

$\square$ P-0-10 cm (n=7) $\square$ P-10-20 cm (n=7)

$\square P-20-30 \mathrm{~cm}(\mathrm{n}=7)$

Dryland $(\mathrm{n}=7)$

$\square$ Paddy soil $(\mathrm{n}=4)$

Figure 3

Potential rates of sediment and soil samples in this study. (a) Potential denitrification rate, (b) potential anammox rate, (c) the contribution of anammox ( $\mathrm{ra} \%$ ), (d) potential $\mathrm{N}_{2}$ production rate, (e) potential $\mathrm{N}_{2} \mathrm{O}$ production rate, $(f)$ the ratio of $\left(\mathrm{N}_{2} \mathrm{O} / \mathrm{N}_{2} \mathrm{O}+\mathrm{N}_{2}\right)$. Different lowercase letters above the boxes indicate significant differences between different groups based on one-way ANOVA with Tukey's test $(P<0.05)$ 

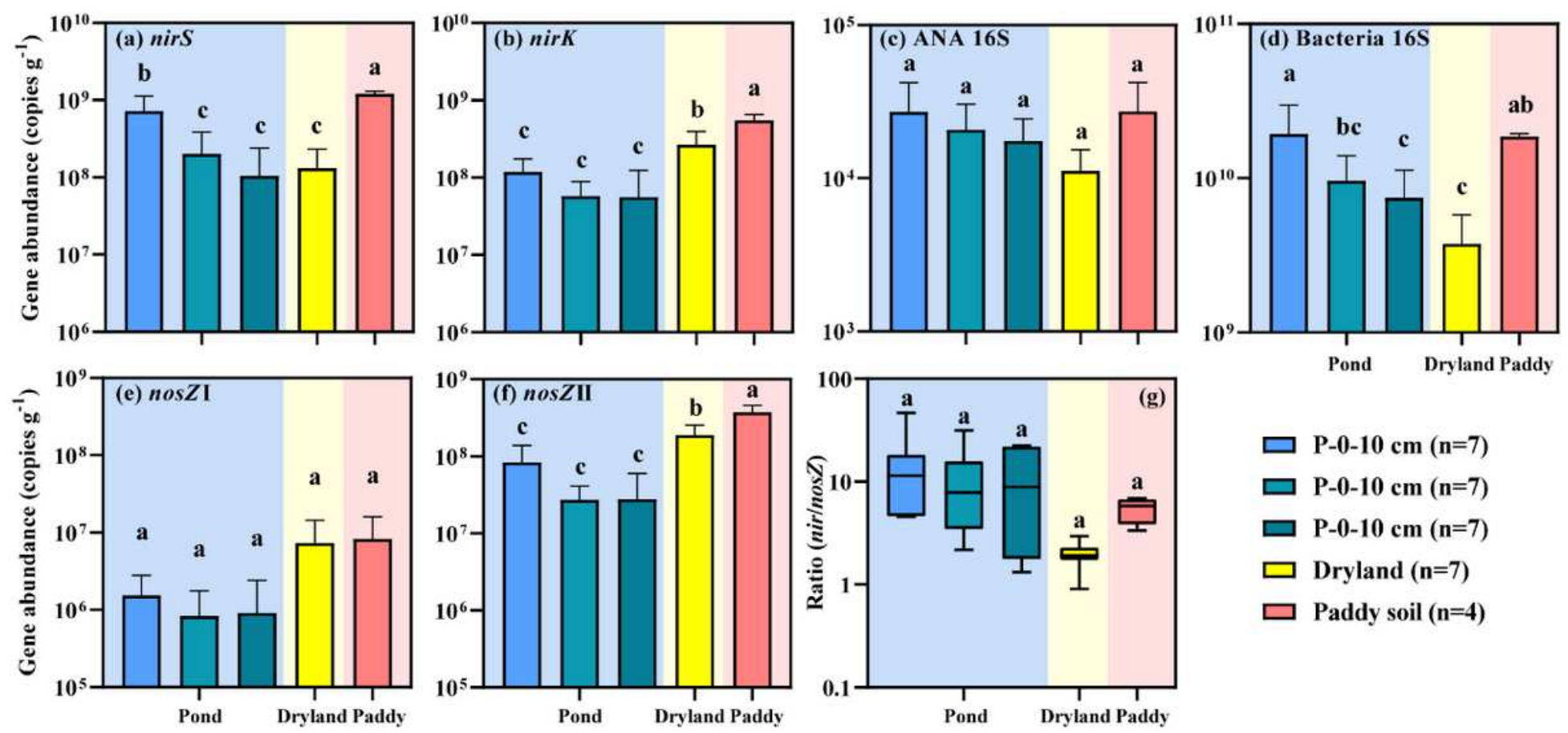

\section{Figure 4}

Abundances of nitrogen removal related genes in this study including (a) nirS gene, (b) nirK gene, (c) anammox 16S rRNA gene, (d) bacteria 16S rRNA gene, (e) nosZ I gene, (f) nosZ II gene, (g) the ratio of nir/ nosZ. Different lowercase letters above the boxes indicate significant differences between different groups based on one-way ANOVA with Tukey's test $(P<0.05)$
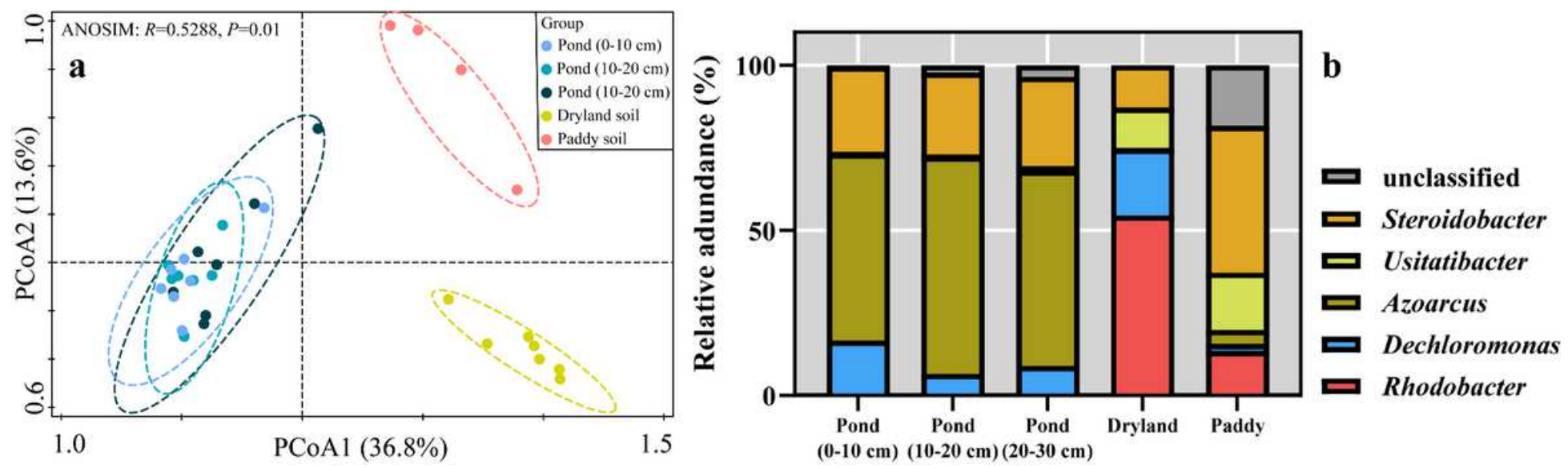

Figure 5

(a) Principal co-ordinates analysis (PCOA) of the nirS gene based on Bray-Curtis distances. (b) Relative abundance of nirStype denitrifiers at the genus level 


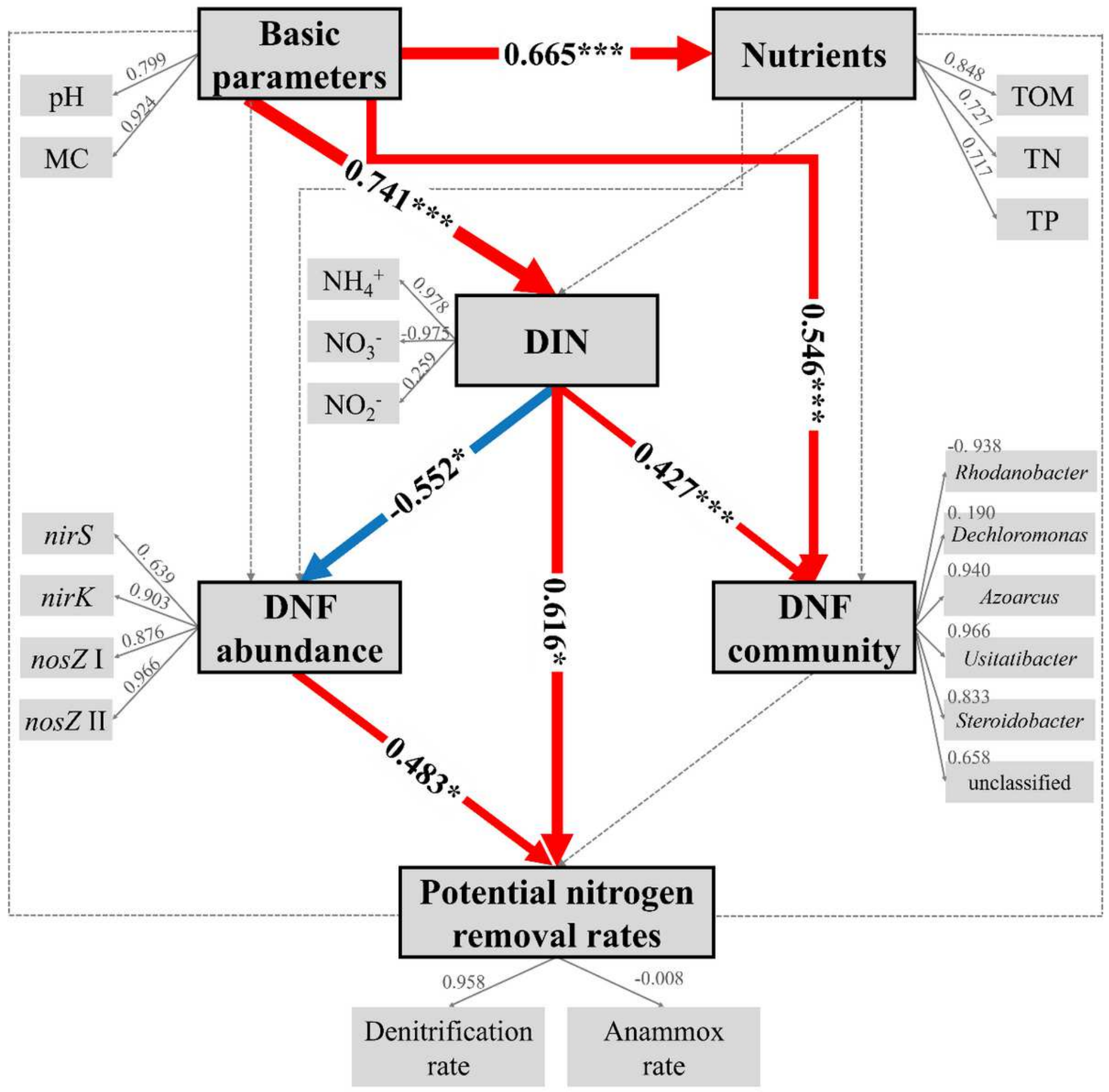

Figure 6

Directed graph of the Partial Least Squares Path Model (PLS-PM). Each box represents an observed variables or latent variables. Path coefficients are calculated after 1000 bootstraps. Coefficients differ significantly from 0 are indicated by $* P \leq 0.05,{ }^{*} P \leq 0.01, * \star \star P \leq 0.001$. The model is assessed using the Goodness of Fit statistic, a measure of the overall prediction performance (The GoF index is 0.58 )

\section{Supplementary Files}


This is a list of supplementary files associated with this preprint. Click to download.

- SupplementaryMaterial.docx 